\title{
Considerations on the Role of the SDR
}




\section{INTERNATIONAL MONETARY FUND}

\section{IMF POLICY PAPER}

\section{CONSIDERATIONS ON THE ROLE OF THE SDR}

IMF staff regularly produces papers proposing new IMF policies, exploring options for reform, or reviewing existing IMF policies and operations. The following documents have been released and are included in this package:

- A Press Release summarizing the views of the Executive Board as expressed during its March 30, 2018 consideration of the staff report.

- The Staff Report, prepared by IMF staff and completed on March 6, 2018 for the Executive Board's consideration on March 30, 2018.

The IMF's transparency policy allows for the deletion of market-sensitive information and premature disclosure of the authorities' policy intentions in published staff reports and other documents.

Electronic copies of IMF Policy Papers

are available to the public from

http://www.imf.org/external/pp/ppindex.aspx

International Monetary Fund

Washington, D.C.

(C) 2018 International Monetary Fund

CInternational Monetary Fund. Not for Redistribution 


\section{INTERNATIONAL MONETARY FUND}

March 6, 2018

\section{CONSIDERATIONS ON THE ROLE OF THE SDR}

\section{EXECUTIVE SUMMARY}

This paper explores whether a broader role for the SDR could contribute to the smooth functioning and stability of the international monetary system (IMS).

Recent staff assessments highlighted that the IMS has displayed considerable resilience. But episodes of stress point also to some weaknesses, including in external adjustment mechanisms; limitations of official liquidity provisions through the Global Financial Safety Net (GFSN); and large-scale reserve accumulation-with systemic side effects. Those weaknesses, together with the expansion of the SDR basket, have renewed interest in the SDR and motivated a discussion of whether there is an economic rationale for a broader SDR role. The paper looks into how those weaknesses can be mitigated by three concepts of the SDR: the official SDR, the reserve asset administered by the IMF (O-SDR); SDR-denominated financial instruments, or "market SDRs" (M$\mathrm{SDR})$; and the SDR as a unit of account (U-SDR). However, the paper does not propose specific reform options.

While the O-SDR currently plays a limited role in contributing to the smooth functioning of the IMS, it could potentially have the greatest scope under a different legal framework. O-SDR allocations could buffer external adjustment, and help reduce precautionary reserve accumulation, although the current Articles of Agreement (AoAs) would need to be revised to address important challenges around scale, targeting and use of O-SDR allocations. And while O-SDRs could provide a flexible source of finance to bolster the Fund's lending capacity, for example to respond to large-scale events, changes to the allocation mechanism and options to create OSDRs outside of the current allocation process to help address gaps in the Fund's lending capacity would again require amendments to the AoAs. The findings are in line with work conducted in 2011, which concluded that the O-SDR could potentially have a more promising role in aiding the IMS but faces challenges.

Widespread M-SDR and U-SDR use would likely make more limited contributions to systemic stability, and face significant implementation challenges.

Diversification properties of the M-SDR and U-SDR could lower valuation changes for the balance sheets of some borrowers and investors. This may reduce the risks of sharp external adjustment and potentially reduce precautionary reserve demand. Systemic benefits of the M-SDR would only come with deep, liquid markets, which may be difficult to generate. Nevertheless, use of M-SDRs and U-SDRs could be mutually reenforcing, exploiting potential complementarities. A supportive environment based on 
official support could help generate network externalities, attracting a sizeable share of transactions. But the impact of any shift in use could also be limited, for instance, by the high correspondence between SDR basket weights and the existing share of currencies in international transactions, and by the ability of many investors to better customize, compared with the SDR, their currency exposures at low cost.

Economic and technological developments will affect the future shape of the IMS, and might affect the SDR's role. The prospect of a more multipolar global economy could exacerbate uncertainties over how international currency usage will evolve, and increase systemic risks around international liquidity and its provision. Further work is needed on how financial technologies (fintech) could impact the IMS and currency usage. For instance, Distributed Ledger Technologies (DLTs) could boost interconnectedness and amplify susceptibility to spillovers and capital flow volatility while influencing the attractiveness of a reserve currency. Such an environment might call for a re-evaluation of the role of the SDR. 
Approved By

Tobias Adrian, Louis Marc

Ducharme, Martin

Mühleisen, Maurice

Obstfeld, and

Andrew Tweedie
Prepared by FIN, MCM, RES, SPR, and STA in consultation with LEG under the guidance of the SDR Steering Group (Xavier Debrun, Daniel Hardy, Alfred Kammer, Kristina Kostial, Signe Krogstrup, Thomas Krueger, Wojciech Maliszewski, Donal McGettigan, and Carlos Sánchez-Muñoz); led by Alberto Behar and Andy Swiston (both SPR); with contributions from Rina Bhattacharya, Joao Jatene, Ceyda Oner, Ezgi Ozturk, JeanGuillaume Poulain, and Sergio Rodriguez-Apolinar (all FIN); Hoang Pham and Anjum Rosha (both LEG); Abdullah Al-Hassan and Hui Miao (both MCM); Yuko Hashimoto, Suman Basu, and Ruy Lama (all RES); Ethan Boswell, Shushanik Hakobyan, Neil Meads, Camilo Tovar, and Frank Wallace (all SPR); and Paul Austin, Joji Ishikawa and Raja Hettiarachchi (all STA). ${ }^{1}$

\section{CONTENTS}

II. THE SDR IN A CHANGING IMS

A. The Role of the SDR Over Time $\underline{6}$

B. IMS Weaknesses Amid Interconnectedness $\underline{10}$

III. ADDRESSING IMS WEAKNESSES WITH THE SDR $\underline{19}$

A. Could the SDR Help Smooth External Adjustment? $\underline{19}$

B. Could the SDR Help Fill Gaps in Official Provision of International Liquidity? $\underline{25}$

C. Could the SDR Help Mitigate the Systemic Side Effects of Reserve Accumulation? $\underline{27}$

\section{COULD THERE BE COMPLEMENTARITIES FROM USE OF THE SDR IN MULTIPLE}

CONCEPTUAL FORMS?

V. THE SDR IN THE FUTURE IMS

A. Uncertain Economic Transitions $\underline{31}$

B. Cryptocurrencies and Distributed Ledger Technologies 34

\footnotetext{
${ }^{1}$ An external advisory group provided feedback to staff in this assessment. The group was convened by the IMF's Economic Counsellor, Maurice Obstfeld, and consists of Claudio Borio, Barry Eichengreen, Yiping Huang, Isabelle Laurent, José Antonio Ocampo, Hélène Rey, Zoeb Sachee, Catherine Schenk, Edwin Truman, and Beatrice Weder di Mauro. Views expressed in this paper are not necessarily those of the members of the group or, where applicable, the institutions with which they are affiliated.
} 


\section{BOXES}

1. Concepts of the SDR _ $\underline{7}$

2. Higher Interconnectedness and Rising Spillovers __ 13

3. How Did Countries Use Their 2009 SDR Allocation?___ 22

4. How Might Official Sector Support Encourage M-SDR Activity?___

5. Distributed Ledger Technologies and Cryptocurrencies___ $\underline{35}$

\section{FIGURES}

1. Strains on the Bretton Woods System___ $\underline{6}$

2. Transition to Floating Exchange Rates___ $\underline{8}$

3. Global Holdings of International Reserves ___ $\underline{9}$

4. Financial Openness___ 10

5. Key Characteristics of International Currencies___ 10

6. Exports and Economic Activity ___ 12

7. Capital Flow Volatility _ـ 14

8. Exchange Rate Anchors ___ 14

9. Elements of the Global Financial Safety Net___ 16

10. Reserve Holders and Instrument Composition___ 17

11. Reserve Flows Relative to Macroeconomic Aggregates of Reserve Currency Issuers ___ 18

12. Schematic Summary of Potential SDR Contributions to IMS __ $\underline{20}$

13. Foreign Exchange Reserves and IMF Quota Shares ___ $\underline{23}$

14. Risk and Risk-adjusted Returns ___ 24

15. Commodity Price Volatility___ $\underline{25}$

16. Precautionary and Non-Precautionary Reserves___ 27

17. Impact of Reserve-Related Liabilities on Current Account Balances___ $\underline{28}$

18. Bid-Ask Spreads and Bond Stocks Outstanding___ 29

\section{TABLE}

1. International Financial Indicators 


\section{INTRODUCTION}

1. To date, the SDR's role in the international monetary system (IMS) has been modest. The official SDR was conceived under the Bretton Woods gold exchange standard as an official reserve asset to supplement other sources of reserves. As the IMS evolved, and despite the aims of the Second Amendment of the Articles of Agreement (AoAs) to make the SDR "the principal reserve asset in the international monetary system" (AoA XXII), its share in reserves has remained small. Interest in the SDR as a unit of account and denomination for financial instruments has been periodic - peaking soon after the collapse of the Bretton Woods par value system - with low overall uptake.

\section{A renewed assessment of the potential contribution of the SDR to a changing IMS is in} order. Discussions based on work published in 2011 did not reach consensus to take forward possible reforms to the SDR. ${ }^{2}$ However, a recent stocktaking of the IMS underscored the increasingly multipolar nature of the global economic and financial system and its rising trade and financial interconnectedness (IMF, 2016a). A diagnostic of the global financial safety net (GFSN) pointed to many strengths, but also to weaknesses in the architecture, and enhancing the role of the SDR was raised as a potential way forward (IMF, 2016b; 2016c; 2017a). The discussion in 2016 on the case for a general allocation or cancellation of SDRs projected that global demand for reserves would continue to increase, but refrained from proposing an allocation, pending further work on the SDR's function as a source of global liquidity and in meeting the global demand for reserves (IMF, 2016d; 2016e). Renewed interest has also come in the wake of the additional SDR allocations in 2009, from inclusion of the Chinese renminbi in the SDR valuation basket (IMF, 2015a) and issuance of SDRdenominated financial instruments in China in late 2016.

\section{This paper discusses whether a broader role for the SDR could contribute to the} smooth functioning and stability of the current IMS. It updates the evaluation of IMS weaknesses before discussing how the SDR might be part of the solution, building on discussions in 2011. In this context, it considers the economic rationale for the O-SDR as a reserve asset, including potentially as a source of finance for conditional lending with attendant amendments to the AoAs. It also considers SDR-denominated financial instruments, or "market SDRs"; and the SDR as a unit of account (Box 1; IMF, 2016f). The emphasis is on the SDR's potential to aid the IMS rather than on specific reforms. ${ }^{3}$ That said, an enhanced role for the SDR cannot substitute for sound policies nor on its own resolve all IMS weaknesses, but may help alongside other efforts, including global coordination, stronger surveillance, and an improved GFSN.

\section{The paper also introduces a discussion of uncertainties in the IMS of the future. The} global economy is becoming more multipolar, which raises questions about how demand for and supply of reserve assets will change. Uncertainties about the geography and timing of such shifts are amplified by potential financial innovations such as distributed ledger technologies (DLTs). This

\footnotetext{
2 Previous work on the IMS includes IMF (2011a; 2010) and work on the SDR includes IMF (2011b; 2011c).

${ }^{3}$ Operational details or discussion of the SDR relative to other mechanisms for addressing IMS weaknesses (e.g., financial regulation, capital flow management) lie outside the scope of this paper.
} 
paper aims to initiate a discussion of how multipolarity and financial innovation may play out and interact, while acknowledging that these topics deserve further analysis in the future.

5. The paper is structured as follows: Section II describes the role of the SDR in a changing and challenging IMS. Section III evaluates whether the SDR could address any IMS weaknesses while outlining relevant hurdles for a broader use of the SDR. Section IV looks into potential complementarities across the SDR's conceptual forms. Section $V$ discusses how a more multipolar world and emerging financial technologies could affect the IMS and the SDR. The final section suggests issues for discussion.

\section{THE SDR IN A CHANGING IMS}

6. The SDR, in any of its conceptual forms, is a component of, and operates within, the IMS. The IMS comprises the set of rules, mechanisms, and supporting institutions that govern international (current and capital) transactions. It contributes to global economic and financial stability by supporting adjustment of external imbalances and facilitating provision of international liquidity while maintaining confidence in the stability of value of the reserve media. This section reviews the role of the SDR in the IMS and the challenges the IMS faces amid increasing interconnectedness.

\section{A. The Role of the SDR Over Time}

7. The Bretton Woods par value system of fixed but adjustable exchange rates and gold convertibility of official U.S. dollar holdings started showing strains in the 1960s. Increases in reserves in the 1960s were accounted for mainly by accumulation of U.S. short-term official liabilities, with the sterling declining in influence, and Germany and Japan resisting the use of their currencies as reserve assets (Figure 1). U.S. liabilities came to exceed U.S. gold holdings by 1965 , and there was a growing recognition that, on prevailing trends, the gold value of official dollar holdings could be vulnerable to a potential shift out of these claims (Ocampo, 2016).

\section{A tradeoff emerged between sufficient supply of international liquidity in the form of foreign exchange and confidence in the value of these claims ("Triffin dilemma"). Reserve} distribution under the Bretton Woods system was to a great extent a zero-sum game. With the U.S. as the dominant reserve supplier, any increase in the collective reserve holdings of the rest of the world would need to be achieved largely through a decline in the net reserves of-and increase in monetary liabilities of-the U.S. (Eichengreen and Frankel, 1996). Under the constraints of the Bretton Woods system, if foreign exchange reserves were not supplied in sufficient quantity to facilitate rapidly-growing trade and capital flows, a shortage of liquidity could impede global 
economic expansion. Conversely, systemically accommodative U.S. policies would facilitate meeting reserve demand, but raise risks of a loss in confidence of the value of its liabilities in terms of gold, undermining the stability of the system by putting pressure on dollar-gold convertibility (Triffin, 1960).

\section{Box 1. Concepts of the SDR}

When referring to the SDR, discussion has usually focused on the official SDR (O-SDR). However, there are multiple SDR-related concepts.

The O-SDR is the reserve asset created in 1969 and defined under the IMF's Articles of Agreement. It is not a currency, but a potential claim on the holdings of freely usable currencies of participants in the SDR Department (currently all IMF members). ${ }^{1}$ The O-SDR is allocated to participants without regard to a member's macroeconomic policies, and can be used unconditionally to obtain freely usable currency to meet a balance of payments need. Under the current framework, allocations are made in proportion to IMF quotas to meet the long-term global need to supplement existing reserves (IMF, 2016d). ${ }^{2}$ Transactions and holdings are limited to participants, the General Resources Account of the IMF (as a result of transactions between participants and the IMF), and prescribed holders. ${ }^{3}$

Since 1974 the O-SDR has been valued based on a basket of currencies, after originally having a value defined in terms of gold. In 2015, in the most recent quinquennial review of the SDR valuation method, the Chinese renminbi was determined by the Executive Board to meet the criteria ${ }^{4}$ for inclusion in the valuation basket, and was included effective October 1, 2016 (IMF, 2015a) alongside the euro, Japanese yen, pound sterling, and U.S. dollar. A new weighting formula was adopted that increases the share and coverage of variables reflecting the use of currencies in international transactions. ${ }^{5}$

An M-SDR is a financial instrument issued by an official or private entity denominated in SDR. All other parameters such as interest rate or maturity are defined by agreement between the parties. For example, MSDRs could include bank deposits, loans, securities, or derivatives.

Use of the SDR as a unit of account, for example to price international trade or for the dissemination of statistics, is referred to as the U-SDR.

${ }^{1 / A}$ freely usable currency is one that the Fund has determined (i) is, in fact, widely used to make payments for international transactions, and (ii) is widely traded in the principal exchange markets (AoA XXX(f)).

${ }^{2 / A l l o c a t i o n s ~ o r ~ c a n c e l l a t i o n s ~ o f ~ O-S D R s ~ r e q u i r e ~ a ~ p r o p o s a l ~ o f ~ t h e ~ M a n a g i n g ~ D i r e c t o r, ~ c o n c u r r e d ~ b y ~ t h e ~ E x e c u t i v e ~ B o a r d, ~}$ and approved by an eighty-five percent majority of the total voting power of the Board of Governors (AoA XVIII, Section 4).

${ }^{3 /}$ Some international financial institutions and regional central banks are prescribed holders, who do not receive allocations but are permitted to hold O-SDRs, pursuant to approval by an eighty-five percent majority of the total voting power of the Executive Board (AoA XVII, Section 3).

${ }^{4 / S p e c i f i c a l l y, ~ t h e ~ r e n m i n b i ~ w a s ~ d e t e r m i n e d ~ t o ~ b e ~ o n e ~ o f ~ t h e ~ f i v e ~ c u r r e n c i e s ~ t h a t ~ a r e ~} 1$ ) issued by IMF members (or monetary unions), which are the largest exporters of goods and services in the past 5 years; and 2) determined by the Fund to be freely usable.

${ }^{5 / T h e ~ O-S D R ~ c a r r i e s ~ a n ~ i n t e r e s t ~ r a t e ~ d e t e r m i n e d ~ b y ~ t h r e e-m o n t h ~ i n t e r e s t ~ r a t e s ~ o n ~ g o v e r n m e n t ~ d e b t ~ i n s t r u m e n t s ~ o f ~ t h e ~}$ currencies in the valuation basket. The O-SDR mechanism is self-financing and levies charges on allocations, which are then used to pay interest on O-SDR holdings.

9. The O-SDR was expected to lower systemic vulnerabilities by increasing reserves while reducing accumulation of short-term official claims on the U.S. The aim in creating the O-SDR was "to meet the long-term global need...to supplement existing reserve assets..." (AoA XVIII, 
Section 1; IMF, 1968). Its value was fixed in terms of gold, yet it paid interest, a combination that was expected to make it an attractive reserve asset. The ability to use it without restriction to meet balance of payments (BOP) needs also aimed at ensuring its attractiveness, and allowed it to facilitate the reallocation of the existing pool of reserve assets. ${ }^{4}$ Given that the O-SDR did not represent the liability of any single issuer, O-SDR allocations were expected to reduce overall demand for dollar-denominated claims, which would permit U.S. BOP adjustment without reserve losses in other countries (Hirsch, 1971).

\section{The first general O-SDR} allocation took place as the IMS was changing dramatically. In 1967, the Board agreed to introduce the SDR to supplement existing reserve assets and an allocation of SDR 9.3 billion took place in 1970-72 (Garritsen de Vries, 1976). The Bretton Woods par value system collapsed in the early 1970s. Convertibility of official U.S. dollar holdings into gold at a fixed price ended in 1971 and major economies moved to a system of flexible exchange rates - albeit reluctantly and on the understanding that it would be temporary (Ocampo, 2016). There was
Figure 2. Transition to Floating Exchange Rates

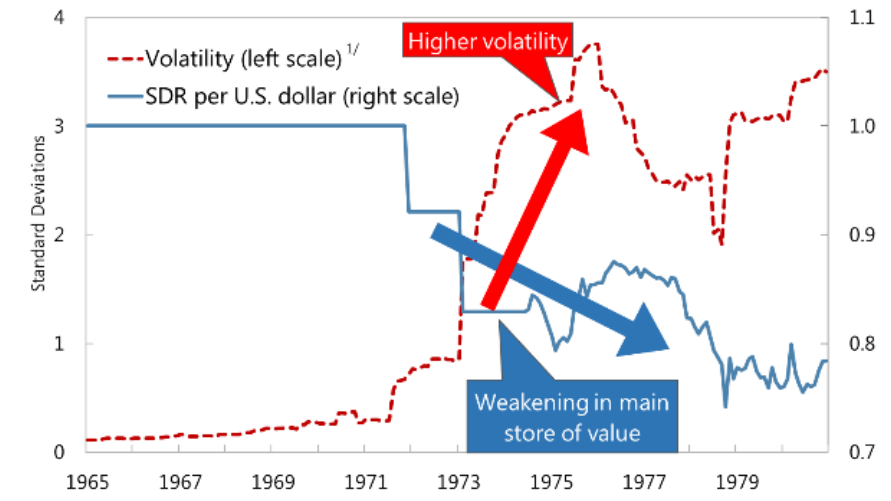

Sources: IMF, International Financial Statistics; Haver Analytics; and IMF staff calculations.

1/ Volatility is measured as the rolling three-year standard deviation of the monthly percent change against the U.S. dollar for the median of the G10 currencies.

also widespread easing of restrictions on capital flows, at first mainly among advanced economies (AEs) and broadening to emerging market and developing economies (EMDEs) in recent decades. This, combined with the development of international capital markets, meant that international liquidity and official liquidity were no longer synonymous, weakening the link between BOP developments in reserve currency issuers and the supply of international liquidity (Bini Smaghi, 2011). In sum, the system in general-and the supply of reserves in particular-became more flexible.

\section{In the wake of these changes, the O-SDR played only a minor role in the IMS. In the} 1970s, the absence of a gold standard, concerns over the dollar due to exchange rate volatility and high inflation prompted interest in the O-SDR (Figure 2). Reforms, including valuation according to a basket of currencies (Box 1), also made the O-SDR a more attractive and stable alternative to claims in national currencies. The second amendment to the AoAs sought to formalize the SDR as the "principal reserve asset of the international monetary system" (AoA XXII; Boughton, 2001), and

\footnotetext{
${ }^{4}$ An IMF member participating in the SDR Department can use its O-SDR to exchange with another participant for freely usable currencies, either by agreement or through the IMF's designation of such another participant. In the latter case, the member is "expected" to use its O-SDR only if the member has a BOP need. The IMF would not challenge the member on the existence of such need, but if the member persists in failing to fulfill this expectation, the IMF may suspend the member's right to use O-SDR. See AoA XIX, Section 3.
} 
interest culminated in the second general allocation of SDR 12.1 billion in 1979-1981. ${ }^{5}$

Counterbalancing this interest in the O-SDR was the view that the evolving IMS could now provide sufficient liquidity through official swaps, official borrowing, and private capital markets, reducing the original rationale for the O-SDR. Furthermore, the unconditional nature of the O-SDR began to raise concerns that it could be used by members to avoid necessary policy adjustment, especially outside the constraints of the Bretton Woods par value system. There was thus a lack of consensus about the SDR's intended purpose in the IMS, limiting support for O-SDR allocations after 1981 and other proposals for the SDR to play a broader role. The SDR's share in global reserves gradually diminished.

\section{During the global financial crisis (GFC), a new O-SDR allocation was used to supplement} reserves. The largest allocation to date, SDR 161.2 billion (equivalent to about US $\$ 250$ billion, or about 3 percent of global reserves at the time), was made effective in August 2009 (Box 3). ${ }^{6}$ It was argued that long-run reserve demand would substantially increase in the aftermath of the GFC. In the context of depressed global economic conditions and deflationary risks, the allocation would help meet this demand in a manner more conducive to systemic stability than policies geared toward additional reserve accumulation (IMF, 2009a). And it would help

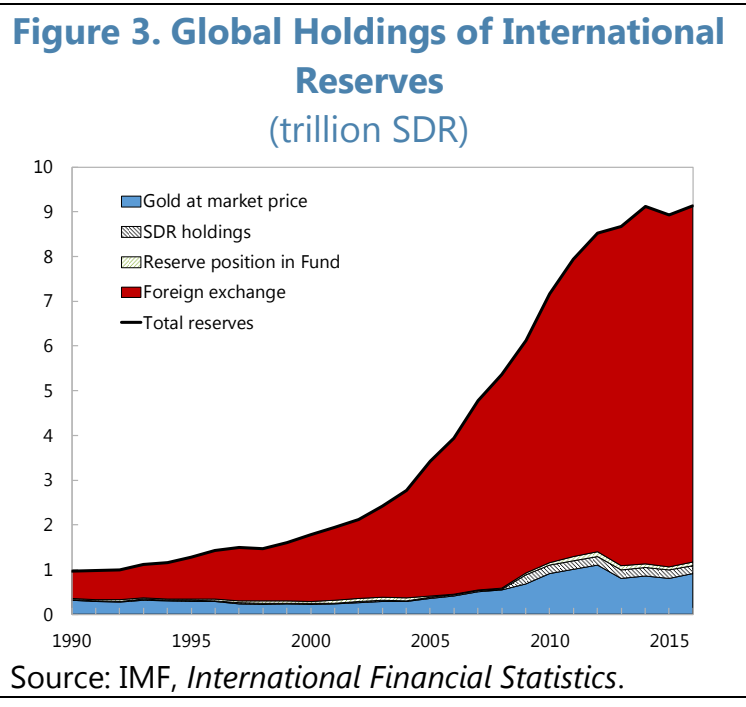
smooth adjustment at the individual country level in the face of a short-term financing shock (IMF, 2009b). The allocation increased reserves substantially for many-estimated at around 19 percent for low-income countries and over 7 percent for emerging markets (excluding China and fuel exporters)—even though overall O-SDR holdings remained small relative to the total stock of reserves (Figure 3). Markets reacted favorably to the allocation, which formed part of the broader G20 crisis response (including tripling the IMF's lending capacity and revamping the IMF's lending facilities) that helped to reduce systemic vulnerabilities.

13. There has also been periodic interest in the U-SDR and M-SDR. With the demise of the gold standard, the U-SDR was adopted as a unit of account by several international organizations and became an exchange rate anchor for some 15 countries. It has also been used for some international commercial transactions such as transit fees for the Suez Canal. M-SDR development

\footnotetext{
${ }^{5}$ Other roles for the SDR considered at the time were as an anchor in a return to a par value system and as a mechanism for countries to diversify their reserve holdings without disrupting markets by creating an account to substitute SDRs for official holdings of gold or foreign exchange (substitution account; see Garritsen de Vries, 1985a; 1985b).

${ }^{6}$ In September 2009, a special allocation of SDR 21.5 billion was made, subsequent to the entry into force of the Fourth Amendment to the AoAs (after initial approval in 1997). This allocation was made to allow members to participate equitably in the SDR, even if they joined the IMF after 1981 and thus had not participated in the previous allocations.
} 
reflected ready-made diversification benefits in an environment of U.S. dollar weakness and an expectation that the SDR would play a greater role in the IMS. SDR-denominated instruments issued by private and public entities comprised commercial bank deposits, syndicated credits, certificates of deposit, Eurobonds, and floating-rate instruments, while demand deposit accounts offered transactions directly in SDR (Hoguet and Tadesse, 2011). However, subsequent U.S. dollar strength and development of alternative diversification options suppressed interest in a broader use of the $\mathrm{U}-\mathrm{SDR}$ and M-SDR. Moreover, use of the SDR as an exchange rate anchor has fallen to three countries (IMF, 2016f). ${ }^{7}$ Only more recently has there been renewed interest following M-SDR bond issuances in China.

\section{B. IMS Weaknesses Amid Interconnectedness}

14. The IMS has evolved, but continues to face challenges. The current IMS has underpinned interconnectedness, which has contributed to income growth and a large decline in world poverty. Relative to the Bretton Woods system, there has been greater flexibility in responding to shocks and crises. Nevertheless, as set out in staff's recent stocktaking of the IMS (IMF, 2016a) and described below, increased interconnectedness amplifies the effects of financial frictions on the functioning of the IMS and can complicate macroeconomic management. These expose weaknesses in the IMS: large spillovers and volatility in capital flows are exacerbating weaknesses in external adjustment, underscoring the limitations of official liquidity provision through the GFSN, and driving large-scale reserve accumulation with systemic side effects.

\begin{tabular}{|c|c|}
\hline $\begin{array}{c}\text { Figure 4. Financial Openness } \\
\text { (gross external assets plus liabilities, in } \\
\text { percent of GDP, median of country group) }\end{array}$ & $\begin{array}{l}\text { Figure 5. Key Characteristics of International } \\
\qquad \text { Currencies }^{1 /}\end{array}$ \\
\hline $\begin{array}{l}500 \text {-Advanced Economies } \\
400 \\
350 \\
300 \\
250 \\
200 \\
150 \\
\text { Sources: Updated data based on Lane and Milesi- } \\
\text { Ferretti (2007); and IMF staff calculations. }\end{array}$ & $\begin{array}{l}\text { IMF, International Financial Statistics; IMF, World Economic } \\
\text { Outlook; and IMF staff calculations. } \\
\text { 1/ Includes issuers with S\&P credit rating of A- or above and } \\
\text { 2016 GDP at market exchange rates greater than } \\
\text { SDR 300 billion (bubbles are sized by GDP). Liquid liabilities } \\
\text { include central government debt and monetary base. }\end{array}$ \\
\hline
\end{tabular}

\footnotetext{
${ }^{7}$ The case of the European Currency Unit (ECU) provides an instructive contrast, as a wide range of ECU markets developed, supported by expectations of eventual European monetary unification (Allen, 1990).
} 


\section{The IMS operates in a complex interconnected economic and financial environment.} From 1990 through 2015, as countries integrated rapidly through trade, exports of AEs increased from 18 to 30 percent of GDP and exports of EMDEs rose from 12 to 26 percent of GDP. At the same time, the global trade network has become more integrated and complex, with some EMDEs becoming hubs. International financial integration also increased dramatically, both in terms of the size of cross-border positions (Figure 4) and the number of large connections. However, financial integration was slower in EMDEs, leaving a substantial gap relative to AEs that, if narrowed with convergence, could amplify capital flow volatility (IMF, 2016a; 2016b).

\begin{tabular}{|c|c|c|c|c|c|c|}
\hline \multicolumn{7}{|c|}{$\begin{array}{c}\text { Table 1. International Financial Indicators } \\
\text { (shares in percent of global total) }\end{array}$} \\
\hline & $\begin{array}{c}\text { Foreign } \\
\text { Exchange } \\
\text { Market } \\
\text { Turnover }\end{array}$ & $\begin{array}{l}\text { Cross-Border } \\
\text { Payments }\end{array}$ & $\begin{array}{c}\text { International } \\
\text { Banking Liabilities }\end{array}$ & $\begin{array}{c}\text { International } \\
\text { Debt Securities }\end{array}$ & $\begin{array}{c}\text { Official Foreign } \\
\text { Exchange } \\
\text { Reserves }\end{array}$ & $\begin{array}{l}\text { SDR Basket } \\
\text { Weights } 1 /\end{array}$ \\
\hline & 2016: April & 2014:Q3-2015:Q2 & 2016: Q4 & 2016: Q4 & 2017: Q2 & Percent \\
\hline USD & 43.8 & 42.7 & 54.8 & 46.6 & 63.8 & 41.55 \\
\hline EUR & 15.6 & 35.4 & 25.2 & 37.5 & 19.9 & 32.07 \\
\hline GBP & 6.4 & 4.1 & 4.6 & 8.0 & 4.4 & 8.03 \\
\hline JPY & 10.8 & 3.4 & 3.1 & 1.9 & 4.6 & 7.44 \\
\hline RMB 2/ & 2.0 & 1.1 & 1.0 & 0.4 & 1.1 & 10.91 \\
\hline Other & 21.4 & 13.2 & 11.2 & 5.6 & 6.2 & n.a. \\
\hline \multicolumn{7}{|c|}{$\begin{array}{l}\text { Sources: IMF staff calculations based on data from Bank for International Settlements, and IMF Currency } \\
\text { Composition of Official Foreign Exchange Reserves survey. } \\
\text { 1/ As of October 27, 2017. Actual currency weights in the SDR basket may change on a daily basis due to exchange } \\
\text { rate movements. } \\
\text { 2/ RMB ranked 8th in foreign exchange market turnover, 5th in international banking liabilities outstanding, 10th in } \\
\text { international debt securities outstanding, and 7th in official foreign exchange reserves. }\end{array}$} \\
\hline
\end{tabular}

\section{Economic developments in currency issuers can play an outsize role. National} currencies-most prominently, the U.S. dollar and the euro-play international roles as means of payment and unit of account (Table 1), and "safe assets" denominated in these currencies provide stores of value and ready access to international liquidity. These global roles are determined by fundamentals (economic size of the issuer, depth and liquidity of financial markets, credibility of domestic macroeconomic policies, and broader institutional strength), network externalities, and habit formation (Figure 5). The resulting concentration of trade and financial transactions in a few currencies creates the potential for economic developments in those currency issuers to be much more important than their direct weight in international commerce. ${ }^{8}$

17. As financial integration increases, frictions become more challenging. In a financiallyintegrated world, capital flows can intensify macroeconomic volatility through boom-bust cycles, especially given their tendency to be more procyclical than domestic credit (Borio and others, 2011; Lane and McQuade, 2014). Sharp reversals in capital flows have been associated with feedback loops

\footnotetext{
${ }^{8}$ See Eichengreen (2011), Prasad (2014), Aizenman (2013), Obstfeld and others (2010), and Goldberg and Tille (2009).
} 
of financial system distress, forced asset sales and pullbacks in lending, output losses, and further deterioration in balance sheets (Calvo and others, 2008). Herding and contagion effects can exacerbate these episodes (Agosin and Huaita, 2012; Forbes and Warnock, 2012).

18. Cross-border spillovers have been increasing. ${ }^{9}$ Empirical studies confirm that higher interconnectedness has increased economic spillovers (Box 2). Rising trade ratios have bound countries' economic fortunes more tightly, as illustrated by the increasing correlation between fluctuations in GDP and export growth rates (Figure 6). Similarly, the magnitude of capital flow swings has increased (Figure 7; IMF, 2016g). Asset prices have become more correlated across countries. Financial integration transmits financial conditions across borders, even under flexible exchange rates, which offer only partial insulation of countries' monetary policies from global cycles (Obstfeld and others, 2018; Rey, 2015). In particular, conditions in the issuers of international reserve currencies have a sizable impact on domestic financial conditions across a wide range of countries. In EMDEs, transmission is larger and especially sensitive to the degree of financial integration (Miranda-Agrippino and Rey, 2015; IMF, 2017b).

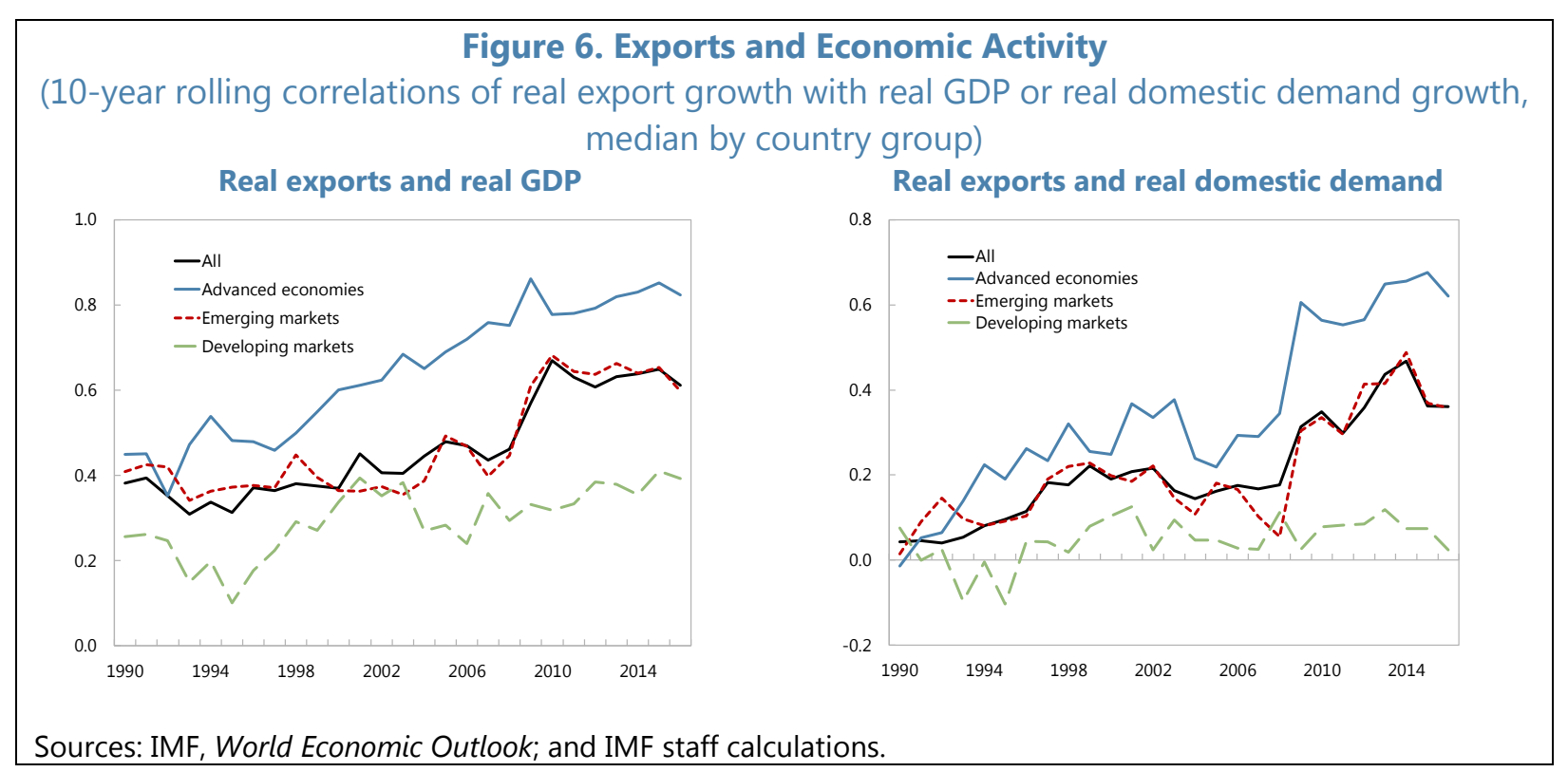

\footnotetext{
${ }^{9}$ Spillovers are defined here as the transmission of economic and financial conditions from one economy to another, whether due to the influence of economic linkages or increased exposure to contagion.
} 


\section{Box 2. Higher Interconnectedness and Rising Spillovers}

Macroeconomic theory gives ambiguous predictions about the effects of interconnectedness on the transmission of economic and financial conditions across countries. However, the empirical literature generally finds that higher linkages raise spillovers through several channels, with financial spillovers tending to be episodic.

Studies have documented a connection between higher trade integration and a larger impact of external factors on the domestic economy. Studies measuring bilateral trade linkages using gross trade reached mixed conclusions, but empirical work focusing on value-added trade finds that higher trade linkages have a significant impact on business cycle synchronization and transmission of country-specific shocks (Duval and others, 2016). There is also evidence that broader trade openness increases exposure to global financial shocks by making domestic financial conditions more sensitive to global ones (IMF, 2017b). This was evident during the GFC, as countries with higher ratios of trade-to-GDP experienced a larger impact on economic activity relative to pre-crisis forecasts (Berkmen and others, 2012).

A number of channels have been identified by which higher financial interconnectedness transmits financial conditions across borders. There is a direct channel via interest rates, as more financially open economies have been shown to have a higher co-movement of domestic interest rates with both policy and long-term rates in reserve currency issuers (Aizenman and others, 2016). There are links between shocks in reserve currency issuers and cross-border capital flows, implying countries with larger cross-border positions are more exposed to potential spillovers. Cetorelli and Goldberg (2011) establish that this impact can occur through cross-border bank lending, local lending of foreign bank affiliates, or effects on the credit supply of domestic banks that rely on cross-border interbank funding, while Sahay and others (2014) document similar spillovers through portfolio flows. Finally, a risk-taking channel has been identified, by which changes in risk aversion in global markets spill over into returns of risky assets around the world, including via capital flows (Ahmed and Zlate, 2014).

Rising financial interconnectedness seems to result in spillovers that are more episodic in nature. The effects of higher financial integration on business cycle synchronization in normal times are mixed, with studies finding effects in either direction (Imbs, 2006; Kalemli-Ozcan and others, 2013a), and evidence suggesting no upward trend in the share of fluctuations in domestic output or financial conditions accounted for by global financial shocks—when excluding the GFC (Abbate and others, 2016; IMF, 2017b). However, the impact of the GFC on output was higher for countries with higher bilateral U.S. financial linkages, as well as for those with higher overall financial integration (Kalemli-Ozcan and others, 2013b; Imbs, 2010). This presents an overall picture of financial spillovers that are episodic in nature and potentially non-linear, consistent with swings in risk aversion playing a prominent role in their transmission (HausmanGuil and others, 2016). 
Figure 7. Capital Flow Volatility

(change in gross flows, percent of GDP, 10-year rolling standard deviation, median by country group)

Liabilities

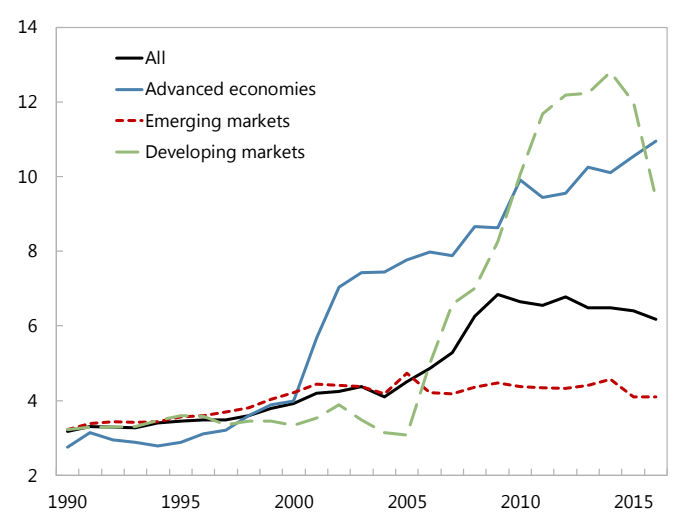

Assets

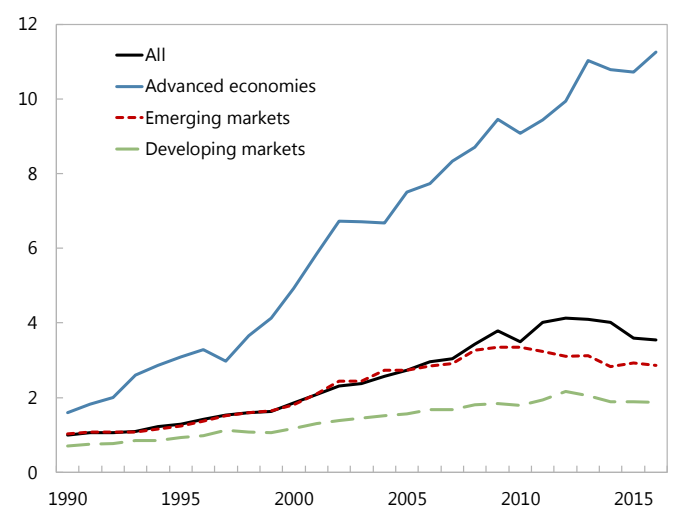

Sources: IMF, World Economic Outlook; and IMF staff calculations.

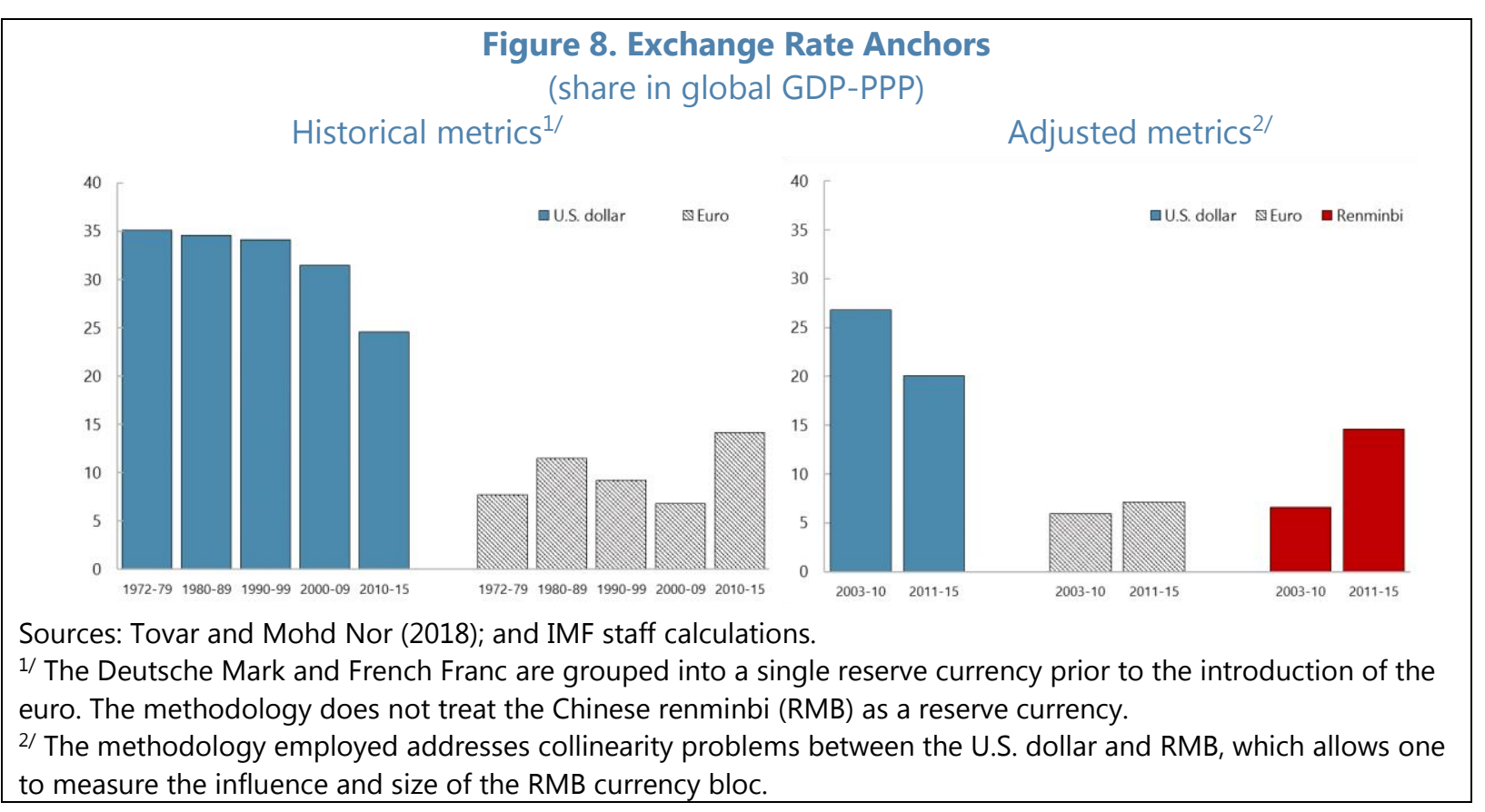

\section{Macroeconomic management has become more complicated by tradeoffs among currency stability, independent monetary policy, capital mobility, and financial stability.}

Countries accounting for a significant proportion of the global economy still anchor their currencies (Figure 8; Ilzetzki and others, 2017). ${ }^{10}$ In spite of this, many still pursue independent monetary policy, requiring an augmented policy toolkit with capital flow management or macroprudential measures

\footnotetext{
10 Tovar and Mohd Nor (2018) refer to a currency as anchored when it is pegged to a reserve (anchor) currency or if changes in the currency's value are mainly explained by the factors that change the value of the reserve (anchor) currency.
} 
(IMF, 2015b). The coordination among instruments and interaction between their effects can add to complexity and may generate unintended consequences for other countries. ${ }^{11}$ Countries with flexible exchange rates, in particular those with large cross-border liabilities, have increasingly faced tradeoffs between financial stability and currency flexibility, giving rise to an increased need for domestic lending of last resort operations in foreign currency for central banks during episodes of disorderly market conditions (Obstfeld, 2013; Borio and others, 2014). An example of this was the foreign currency funding stress in AEs during the height of the GFC, which resulted in a new set of central bank foreign currency swap arrangements in some AEs (Obstfeld, 2013). ${ }^{12}$

20. Increased interconnectedness helped expose weaknesses of the IMS. Of these, there are three that the SDR might help address: (a) weak external adjustment mechanisms, (b) limitations of official liquidity provision through the GFSN, and (c) large-scale reserve accumulation with systemic side effects. The weaknesses discussed in the rest of this section lay the foundation for examination of how a broader role for the SDR could improve the functioning of the IMS in Section III.

\section{Despite a system of flexible exchange rates, external adjustment has been challenging.}

After the GFC, real exchange rate adjustments played a limited role in reducing current account imbalances, because imbalances and subsequent exchange rate movements were only loosely related. Moreover, those currency movements generated weak trade volume and growth responses (IMF, 2014). Some factors may be contributing to a longer-term weakening of adjustment mechanisms:

- Capital flow volatility has resulted at times in sharp and sudden adjustments in exchange rates, which have tended to be contractionary since the effects of a depreciation on domestic demand have exceeded any expansionary trade effects (IMF, 2016a). ${ }^{13}$ Since such episodes often (but not always) occur amid large current account deficits, and since countries with surpluses do not face such pressures, this underscores the asymmetric adjustment problem that has been identified as a long-standing feature of the IMS (Ocampo, 2014).

- Changes in the structure of trade: Trade pricing in a small number of dominant currencies can inhibit external adjustment due to an asymmetric short-run response of trade flows to exchange rate movements (Gopinath, 2015; Casas and others, 2016). ${ }^{14}$ Specifically, with dominant currency pricing, a depreciation against the dominant currency may reduce real imports but has no impact on real exports. Thus, the use of a dominant currency for trade invoicing can lead to a

\footnotetext{
11 See Dooley and others (2003); Gagnon (2013); Bayoumi and others (2015); Ghosh and others (2017).

12 While the central banks in AEs could institutionalize bilateral swap lines to meet potential needs for foreign currency, EMDEs with flexible exchange rates do not have such assured sources of foreign exchange liquidity, and are likely to hold foreign reserves independently of other motives such as exchange rate management.

${ }^{13}$ Large devaluations can also increase real income inequality because poorer households spend a larger portion of their income on tradable goods (Cravino and Levchenko, 2017).

${ }^{14}$ For countries that invoice a large portion of their exports and imports in U.S. dollars, depreciation of their own currency would not make their exports more competitive and would make their imports more expensive. On the other hand, a dollar depreciation will make most U.S. exports cheaper given that most of its exports are invoiced in dollars. Consequently, in a world with dominant pricing in U.S. dollars, trade balance adjustments primarily happen through U.S. exports and rest-of-the-world imports.
} 
more muted external adjustment in response to exchange rate movements. This can be exacerbated by the rising share in global trade of EMDEs, which use the dollar more widely in pricing. ${ }^{15}$ Also, the relationship between real exchange rate adjustment and trade flows may have been weakened by the build-up of global value chains. ${ }^{16}$

\section{There are limitations in the official provision of international liquidity. The} official GFSN, which includes bilateral swap lines, regional financing arrangements, and IMF resources, has been armed with increased resources and new instruments since the GFC (Figure 9). However, access is unpredictable, coverage is uneven, coordination among layers is underdeveloped and often untested; for many borrowers, political costs in accessing some elements are high (IMF, 2016b; 2016c; 2016h).

\section{Self-insurance through reserve accumulation has been a central policy} response. Increased interconnectedness and volatility raise the importance of countries following sound policies, but also the costs of changes in market sentiment. As such, many countries self-insure by accumulating large foreign exchange reserves. Reserve holdingsmostly in the form of liabilities (mainly sovereign securities) of residents of the main international currency issuers-remain the primary liquidity
Figure 9. Elements of the Global Financial Safety Net (percent of world GDP)

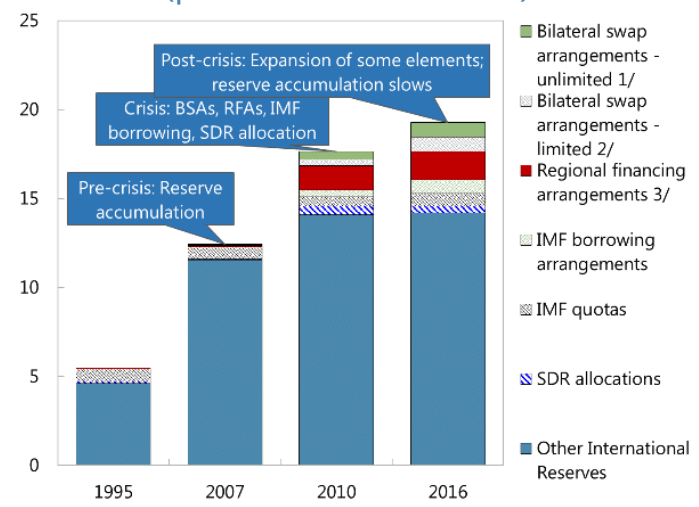

Sources: National central banks; IMF, International Financial Statistics; and IMF staff estimates.

1/ Unlimited swap arrangements are estimated based on known past usage or, if undrawn, on average past maximum drawings of the remaining central bank members in the network. Two-way arrangements are only counted once.

2/ Limited-value swap lines include all arrangements with an explicit value limit and exclude all CMIM and NAFA arrangements, which are included under RFAs. Two-way arrangements are only counted once.

3/ Based on explicit lending capacity/limit where available, committed resources, or estimated lending capacity based on country access limits and paid-in capital.

buffer for most countries and have increased substantially since the late 1990s (Figure 9) across most EMDEs and a few AEs (Figure 10). ${ }^{17}$ Empirical analysis of reserve demand confirms that precautionary motives have played an important role, as accumulations have been associated with the size of cross-border liabilities, past occurrence of crises, as well as exchange rate regimes (Obstfeld and others, 2010; Obstfeld, 2013; Ghosh and others, 2014). Wider private demand for reserve assets can add to official sector demand, particularly when the safety of other assets is questioned (Caballero and Farhi, 2014).

\footnotetext{
${ }^{15}$ Data suggest that the dollar is used to invoice at least 40 percent of global trade not involving the U.S. and is even more prominent in developing Asia and Latin America. The euro is more commonly used in trade involving the European Union (Ito and Chinn, 2015; Goldberg and Tille, 2008). Dollar pricing is a factor in limited trade responses to exchange rates among oil exporters (Behar and Fouejieu, 2017).
}

16 Ahmed and others (2017) and Cheng and others (2016) find evidence for this effect, while Leigh and others (2017) find stability in the relationship between exchange rates and trade volumes.

${ }^{17}$ Foreign exchange reserves play a minor role in a number of large AEs with flexible exchange rates (see also Figure 13 below). 


\section{Figure 10. Reserve Holders and Instrument Composition}

Foreign exchange reserves have increased significantly, to 16 percent of world GDP...

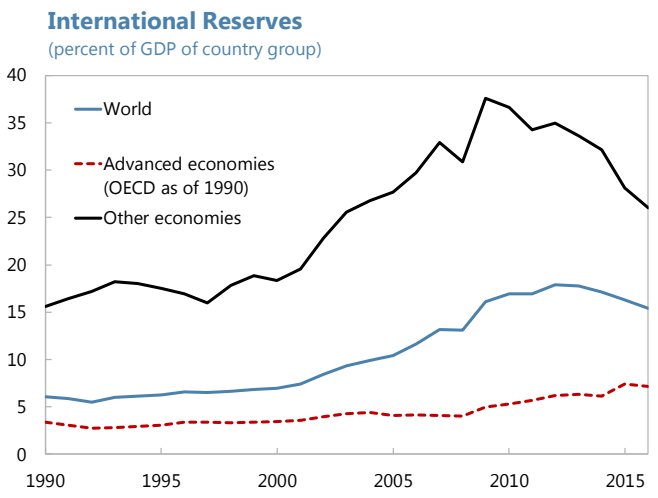

....and a few advanced economies.

Reserves in Advanced Economies (OECD member as of 1990; percent of GDP; number of countries in each bracket)

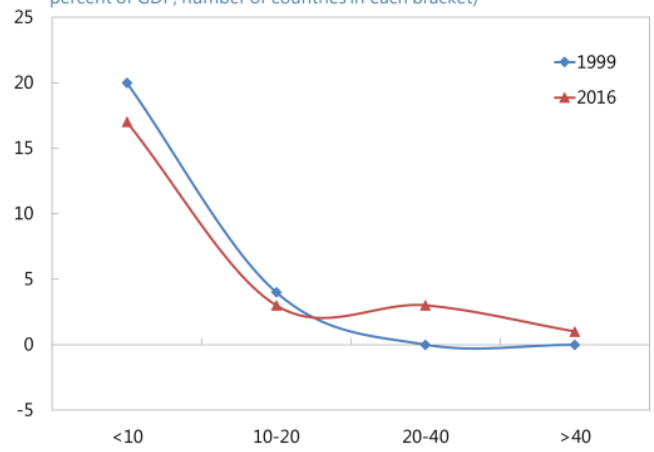

...primarily denominated in the U.S. dollar, followed by the euro...

\section{Currency Composition of Reserves} (percent of identified foreign exchange reserves)

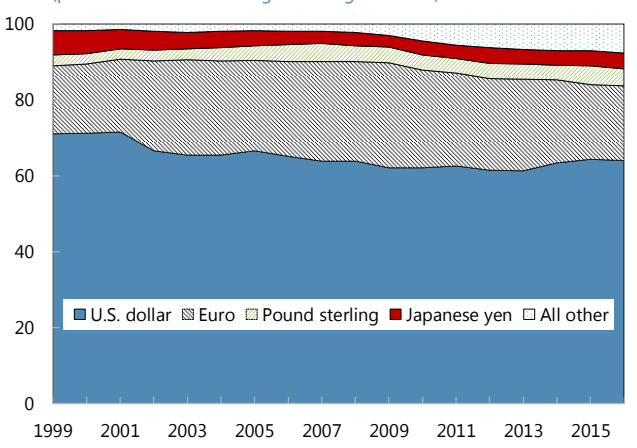

...with a large shift to higher holdings among emerging and developing economies...

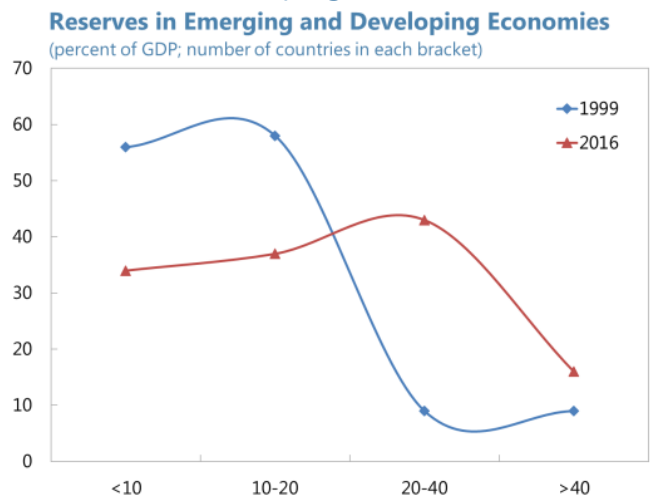

Reserves are comprised principally of securities... Reserve Holdings, 2016 (percent of total)

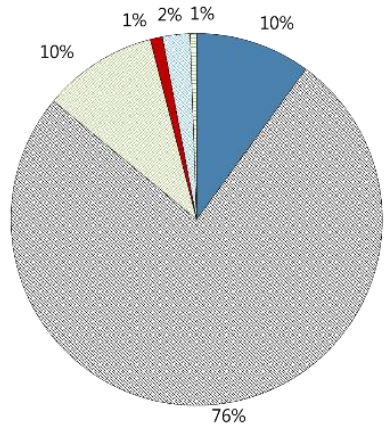

- Currency and deposits

\& Securities

ᄃ Gold

- Reserve position at the IMF

L SDR holdings

E Other reserves

...and issued in large part by residents of those two economies.

Reserve-Related Liabilities (percent of total identified liabilities)

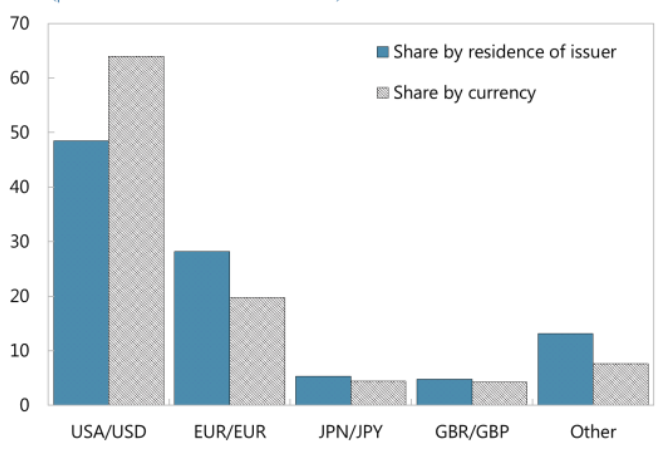

Sources: BIS; Haver Analytics; IRFCL; MBFS; IMF, COFER survey; IMF, International Financial Statistics; IMF, SEFER; IMF, World Economic Outlook; and IMF staff calculations. 


\section{Reserve holdings may enhance systemic resilience and allow countries to smooth} adjustment. Foreign exchange reserves can be used by holders to smooth disruptive external adjustment and allow central banks to conduct domestic lending of last resort operations in foreign currency to preserve financial stability. Sufficient levels of reserves available for such purposes, even without their active use, can strengthen confidence and reduce the probability of self-fulfilling crises, which, among other factors, could explain the modest usage by large reserve holders. In turn, this reduces spillovers faced by others and contributes to enhanced systemic stability (Llaudes and others, 2010; IMF, 2011d; Gourinchas and Obstfeld, 2012).

\section{But excessively large reserve accumulation can have negative systemic side effects such as larger external imbalances and balance sheet risks, inefficient consumption and investment, and distorted interest rates. ${ }^{18}$ Figure 11 provides some} indicative benchmarks on the macroeconomic scale of reserve flows for reserve currency issuers in recent decades, suggesting potentially significant macroeconomic effects, particularly in the U.S. Reserve-related flows could generate a number of effects both in reserve currency issuers and countries engaging in large-scale reserve accumulation: ${ }^{19}$

- External imbalances: Several studies show that reserve-related liabilities generate larger current account deficits for reserve currency issuers and that reserve accumulation raises the current

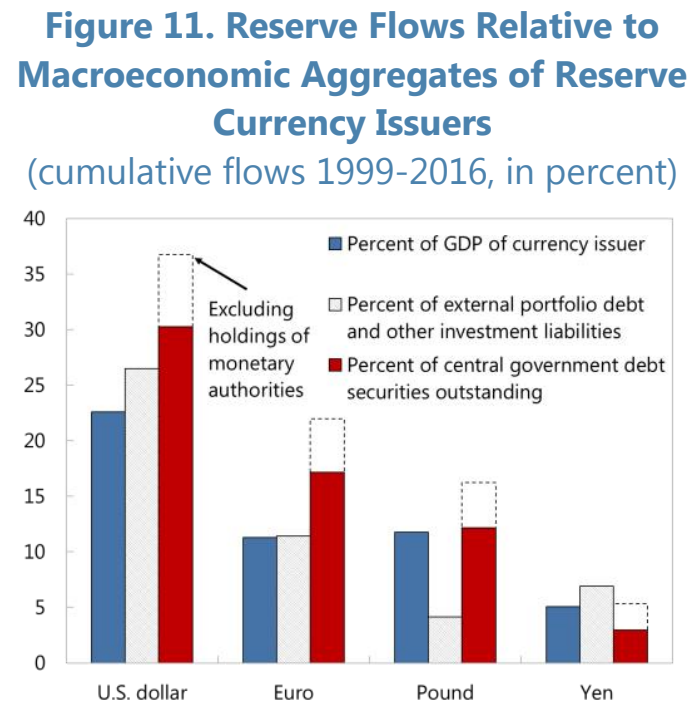

Sources: National sources; Haver Analytics; IMF, COFER survey; BIS; and IMF staff calculations. account of the accumulating country (for example, Gagnon, 2013). Empirical estimates from the IMF's EBA model also find an association between a currency's share in international reserves and a currency issuer's current account deficit (given the multilateral constraint on current account balances, the current account deficits of reserve currency issuers are mirrored by surpluses of the same magnitude in reserve holders). Although the direction of causation is debated (Obstfeld, 2017), this suggests that lower and more diversified reserve-related flows could lessen the pressure toward current account deficits in reserve currency issuers and surpluses in countries engaging in large-scale reserve accumulation.

- External balance sheet risks: Reserve-related inflows and subsequent outflows into riskier investments (including equity and foreign direct investment) are found to be related to safe asset providers' superior financial intermediation capacity (Mendoza and others, 2009). These

\footnotetext{
${ }^{18}$ It is generally recognized that what constitutes adequate or excessive reserves depends to some extent on a country's exchange rate regime, as well as other considerations such as foreign exchange liquidity needs for financial stability (IMF, 2016k).

${ }^{19}$ Although the discussion here focuses on the systemic effects of reserve accumulation, reserves could be costly at the individual country level; reserve purchases generally result in lost interest income and exposure to potentially large capital losses in case of strengthening of the domestic currency against reserve currencies. Large reserve holdings in effect remove substantial amounts of high-quality liquid assets from the market, contributing in some measure to recent signs of reduced liquidity in securities markets.
} 
flows raise the reserve currency issuers' external balance sheets and their exposure to external shocks (Maggiori, 2017). Furthermore, with reserve-related flows easing financial conditions in reserve currency issuers, borrowing in those currencies becomes more attractive for others, posing increased risk of currency mismatches (McCauley and others, 2015).

- Inefficiency in consumption and investment: Reserve-related flows help sustain inefficiencies in the allocation of consumption and investment across countries, by diverting capital from highproductivity to low-productivity investments. Alfaro and others (2014) find that the reserverelated investments and other official flows help explain the capital flows from faster-growing to slower-growing economies.

- Interest rates: Foreign official holdings have a sizable impact on the U.S. Treasury yield curve: a reduction in foreign holdings of U.S. Treasuries by $\$ 100$ billion would increase yields by $1.5-1.8$ basis points (Csonto and Tovar, 2017). ${ }^{20}$ Reserve-related flows have thus contributed to reserve currency issuers being disproportionately affected by the lower bound (Caballero and others, 2016). At the same time, reserve currency issuers benefit disproportionately from the use of their currencies as reserves, deriving seigniorage benefits from the ability to borrow more cheaply than would otherwise be possible.

\section{ADDRESSING IMS WEAKNESSES WITH THE SDR}

\section{The above considerations lay the foundation for discussion of how a broader role for} the SDR could address the identified weaknesses of the IMS. Previous assessments have identified options to strengthen the IMS and emphasized a potential enhanced role of the O-SDR, but analysis of the economic effects of the M-SDR or U-SDR has not been undertaken systematically (IMF, 2010a; 2010b; 2011a; 2011b; 2016c). This section discusses which conceptual forms of the SDR might address three weaknesses of the IMS identified in Section II.B, namely by (a) smoothing external adjustment, (b) addressing gaps in official international liquidity provision, and (c) mitigating any systemic side effects of reserve accumulation. ${ }^{21}$ It also discusses the major challenges to the SDR assuming a greater role. The discussion tentatively suggests that the O-SDR may potentially have a more promising role than the M-SDR or U-SDR (see Figure 12 for a highly stylized schematic diagram), but there are also important challenges for a broader role of the O-SDR.

\section{A. Could the SDR Help Smooth External Adjustment?}

\begin{tabular}{|l|l|l|}
\hline Form & Potential Impact & Drawback \\
\hline O-SDR & $\begin{array}{l}\text { Allocation could provide liquidity } \\
\text { buffers }\end{array}$ & $\begin{array}{l}\text { Lack of conditionality may create moral } \\
\text { hazard; poor targeting }\end{array}$ \\
\hline M-SDR & $\begin{array}{l}\text { Pre-packaged diversification against } \\
\text { capital flow and balance sheet risk }\end{array}$ & $\begin{array}{l}\text { Lack of customization; high cost due to } \\
\text { underdeveloped market; basket revision risk }\end{array}$ \\
\hline U-SDR & $\begin{array}{l}\text { More stable trade receipts/payments; } \\
\text { responsive trade volume adjustment }\end{array}$ & $\begin{array}{l}\text { Limited global impact as SDR valuation } \\
\text { already reflects currency of trade invoicing }\end{array}$ \\
\hline
\end{tabular}

\footnotetext{
${ }^{20} \mathrm{~A}$ rule of thumb estimate indicates that each 1 percent change in foreign exchange reserves (keeping the composition constant) changes Treasury yields by 1 basis point in the opposite direction.

${ }^{21}$ Weaknesses within the IMS may be best addressed directly through improved policymaking, aided by surveillance. Risks due to policy uncertainties and potential for missteps suggest that other options, including a potential enhanced role for the SDR, may also help strengthen the IMS.
} 
Figure 12. Schematic Summary of Potential SDR Contributions to IMS

(if challenges are overcome)

Drivers:

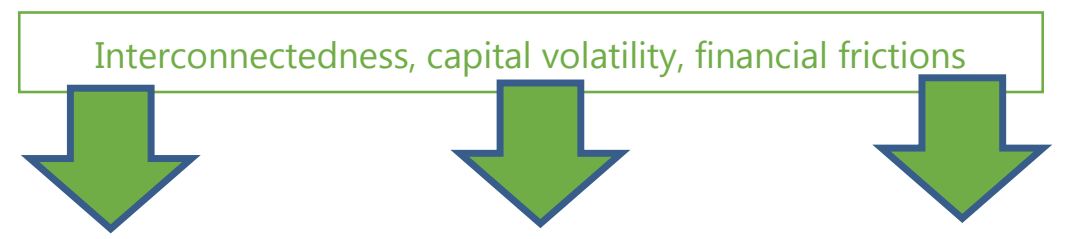

IMS

Weaknesses:

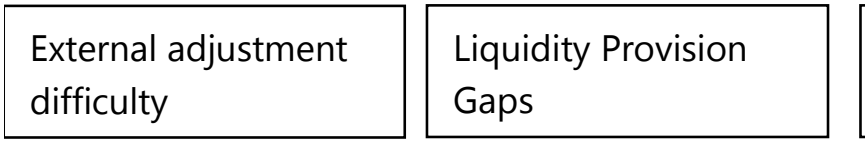

Excess Reserve

Accumulation

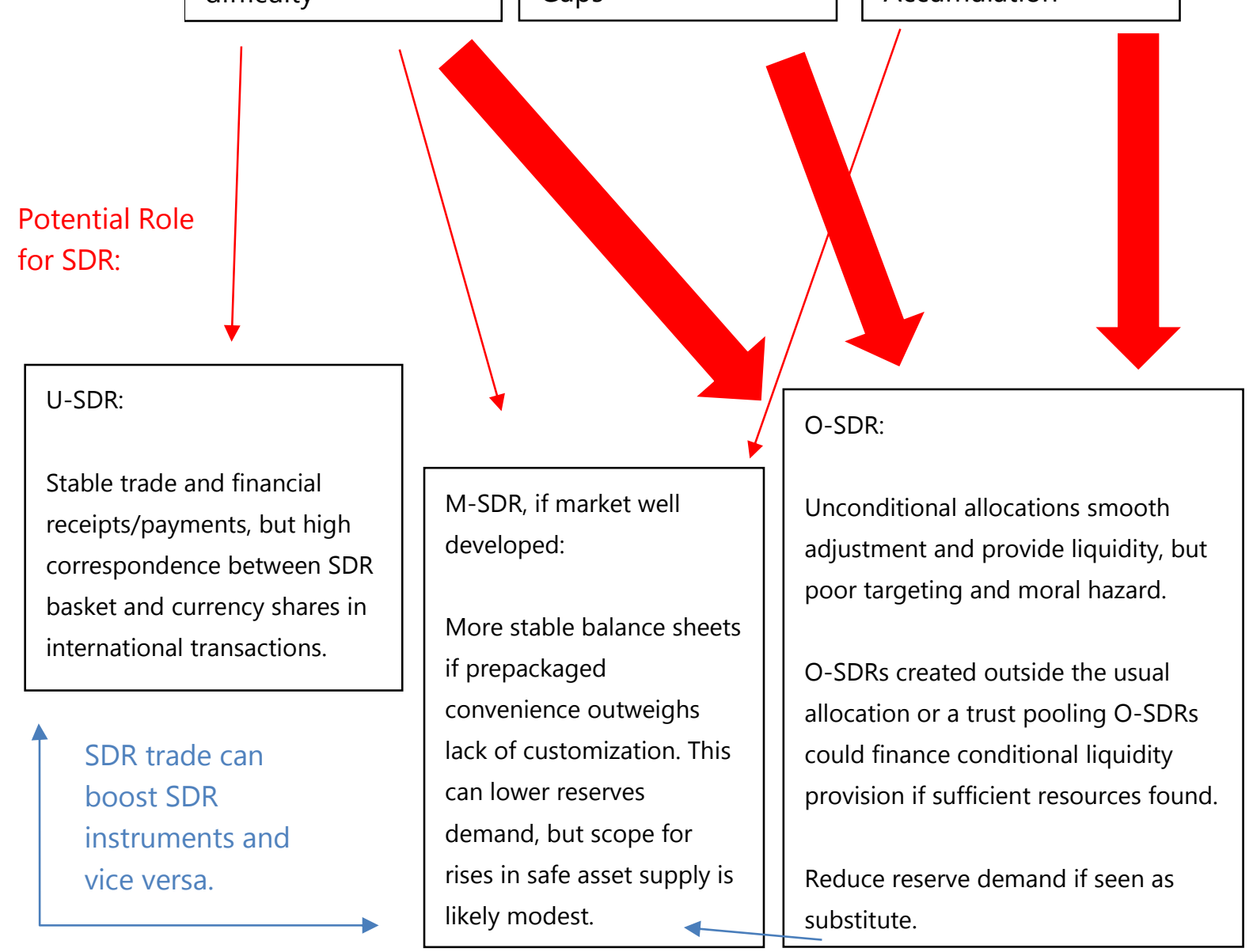

KEY:

Frequent O-SDR exchange rate

Significant systemic impact if challenges overcome

and interest rate updates help

M-SDR pricing.

Modest systemic impact

Complementarities

Scope for official support. 
27. The O-SDR currently plays a limited role in the IMS. Despite the aim of the Second Amendment of the AoAs to make the SDR "the principal reserve asset in the international monetary system," the SDR's role as an international reserve asset has been limited: only the official sector can hold SDRs; there have been only three general allocations; and the global stock of SDRs has averaged just over 3 percent of global reserves since 1970.

28. A lack of consensus around additional O-SDR allocations reflects, in part, moral hazard concerns. With no conditions on the use of O-SDRs, and the reconstitution requirement in abrogation (requiring a country to maintain its average holdings of SDRs at a specified percentage of its allocation over a certain time frame), O-SDRs can conceivably be used to defer warranted macroeconomic adjustment. Evaluating such concerns is complicated by the SDR's modest size relative to reserve holdings (rarely exceeding 20 percent) and limited historical evidence. For the 2009 allocation, staff analysis (IMF, 2016e) and anecdotal evidence from staff reports show some delayed rather than smoothed adjustment, but not widespread misuse (Box 3). While reinstating the reconstitution requirement could go some way toward addressing moral hazard concerns, it would also significantly reduce the attractiveness of the O-SDR as a reserve asset. ${ }^{22}$ More fundamentally, large additional allocations could magnify concerns over reluctance to enact needed adjustment policies including exchange rate flexibility where appropriate. Moreover, they would require enhanced co-operation to finance higher volumes of O-SDR exchange by raising contingent claims on existing foreign exchange reserves, which may cause unease among potential suppliers of such currencies. $^{23}$

29. But additional O-SDR allocations could indirectly facilitate adjustment by increasing liquidity buffers. ${ }^{24}$ The impact of increased O-SDR unconditional allocations on buffers depends crucially on how recipients of the allocations respond. ${ }^{25}$ If the O-SDRs are not fully offset by declines in reserve currency holdings and overall liquidity buffers increase, this may boost confidence and hence reduce the extent of capital outflows, which could reduce the amount of adjustment needed. Also, this should help address the asymmetric adjustment problem by providing a source of financing if large capital outflows materialize. More generally, it can provide the space to support implementation of needed adjustment measures.

\footnotetext{
22 This could be mitigated somewhat through a price-based scheme with a sliding interest rate scale applied to a member's drawdown (IMF, 1980).

${ }^{23}$ Currently, the system relies primarily on voluntary trading arrangements (VTAs) with participants in the SDR Department. It is backed up by the SDR designation mechanism under which participants in the SDR Department whose BOP and reserve positions are deemed sufficiently strong must, when designated, provide freely usable currencies in exchange for O-SDRs up to specified amounts (AoA XIX; IMF, 2016j). VTAs continue to have ample capacity to handle participants' current requests for SDR sales (IMF, 2017c). However, if the role of the SDR were enhanced, analysis would be required on holders' willingness to support the system.

${ }^{24}$ Increased official provision of global liquidity, which will be discussed more fully in Section III.B, could also be supported by using the SDR to finance conditional lending. This can also aid external adjustment.

25 The impact of additional O-SDR allocations may also be affected by broader developments within the GFSN. For instance, regional financial arrangements (RFAs) have grown in size since the GFC, and could theoretically reduce the need for own reserves or O-SDRs, although they remain largely untested.
} 


\section{Box 3. How Did Countries Use Their 2009 SDR Allocation?}

While SDR sales spiked briefly following the 2009 SDR allocation, there is little evidence of widespread moral hazard.

SDRs can be used in a number of ways. The main "use" of SDRs is in supplementing existing official reserves. This can be fulfilled by holding SDRs or by converting them into freely usable currencies through VTAs, changing the composition of reserves. SDRs can also be used indirectly after being converted to freely usable currencies, e.g., to pay for imports, meet external debt obligations, or for intervening in foreign exchange markets. Finally, SDRs can be used directly, e.g., to make quota payments, repurchases, pay charges and fees to the Fund, or to provide resources for the Poverty Reduction and Growth Trust.

What happened after the $\mathbf{2 0 0 9}$ allocation? In the first year following the allocations (September 2009 to September 2010), SDR sales spiked briefly. A total of 21 countries, mostly emerging markets (EMs) and lowincome countries (LICS), sold some SDRs amounting to a relatively small part of the allocation (SDR 3.2 billion). Some 90 percent of these members sold at least 75 percent of their 2009 allocations (excluding sales associated with program-related purchases). Taking a longer period from September 2009 to June 2015, and excluding sales associated with program-related purchases from the Fund, there were 29 sellers. Those with an investment grade rating sold on average about 20 percent of their individual 2009 allocations, while sellers with a non-investment grade rating sold about 40 percent. During this longer period, all 4 investment grade sellers were EMs, while the 25 non-investment grade sellers consisted of 9 EMs and 16 LICs. After the 14th General Review of Quotas became effective in January 2016, around half of the members chose to make part of their quota subscription payments in SDRs rather than in freely usable currencies, possibly using their 2009 SDR allocations. Also, a few borrowing members repaid their IMF loans using the 2009 SDR allocations.

There is little evidence of widespread moral hazard. The allocations were made at the height of the GFC to bolster reserves and help the membership navigate the crisis. Finding evidence that it was used to finance overly-expansionary and/or unsustainable policies, or delayed rather than smoothed needed adjustment, is difficult. That said, if the allocations were used to that end, they could result in higher short-run inflation. Building on Chitu (2016), staff analysis using a difference-in-difference regression finds some modest evidence that the 2009 allocations may have had a short-term inflationary impact, but no long-term effect on inflation. A logit regression analysis over August 2009-December 2010, the peak SDR sales period, finds that countries with fiscal deficits or deteriorating current account balances had a statistically significant higher probability of selling SDRs. Finally, a survey of staff reports over 2009-10 reveals anecdotal evidence of uses by some members of the allocation, including budget financing, that could be seen as delaying the recommended policy adjustment. 
30. Reforms, including alternative targeting mechanisms, could allow a smaller allocation to attain a larger systemic impact. Under the current mechanism, almost 60 percent of any new allocation would accrue to reserve-issuing AEs, who have low reserve demand and are unlikely to use them to avoid external adjustment (Figure 13). For countries where reserve demand is high and O-SDRs could serve as a useful buffer, the share of allocations (around 30 percent) would be well below this group's share of reserve holdings (around 60 percent). Alternative targeting mechanisms, such as one taking into account an individual country's reserve demand, could allow a smaller overall allocation to attain a larger systemic impact. However, alternative mechanisms could amplify concerns about recipients' adjustment incentives and not eliminate unease among potential suppliers of reserve currencies for O-SDR exchange. Alternative allocation mechanisms
Figure 13. Foreign Exchange Reserves and IMF Quota Shares (percent)

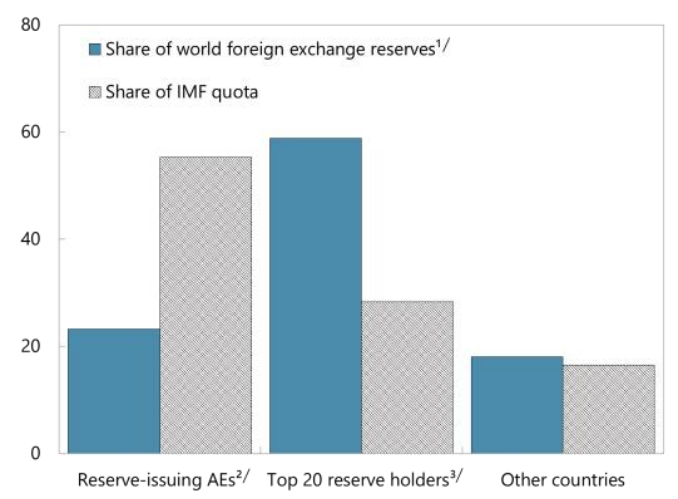

Sources: IMF, International Financial Statistics; Haver Analytics; and IMF staff calculations.

1/ Excludes gold.

2/ According to COFER database, i.e., Australia, Canada, Euro Area, Japan, Switzerland, the United Kingdom, and the United States.

3/ Excludes reserve-issuing Advanced Economies.

\section{There have been proposals for amendments of the current system to allocate O-SDRs} contingent on global conditions and/or meeting policy criteria. O-SDR allocations contingent on global conditions could help countries avoid unwarranted adjustment when a sudden stop in capital flows is unrelated to a country's fundamentals. To reduce allocation uncertainty, regular annual allocations could be put in escrow, with the IMF Executive Board or Board of Governors able to release the O-SDRs at times of systemic stress. Such a scheme would alleviate concerns of misused allocations at normal times, but it would not withhold allocations from countries in need of adjustment. However, such changes would require amendment of the AoAs. Such contingent global allocations could also be combined with ex post or ex ante policy conditionality on countries to incentivize external adjustment or signal confidence in the borrower's policies.

\section{M-SDRs could reduce the sensitivity of balance sheets and capital flows to} developments in any single economy. This would apply particularly to foreign exchange and interest rate risks. The M-SDR, a basket of imperfectly correlated currencies (see Annex I of IMF, 2016f), has less volatile and, for the most part, higher risk-adjusted returns than most equivalent single foreign-currency denominated instruments (Figure 14). ${ }^{26} \mathrm{M}$-SDRs could also lower the sensitivity of capital flows and the overall exposure of economies to developments in any single reserve-issuing economy, alleviating constraints on domestic policy. EMs would stand to benefit the most from the M-SDR's diversification properties due to the natural hedge it can provide their economies. $^{27}$

\footnotetext{
${ }^{26}$ This would also serve to limit the extent of valuation changes in response to fluctuations in the domestic currency. The gains may be limited, however, since most countries' reserve holdings are already partially diversified.

${ }^{27}$ EM financial indicators have been negatively correlated with the U.S. dollar index.
} 


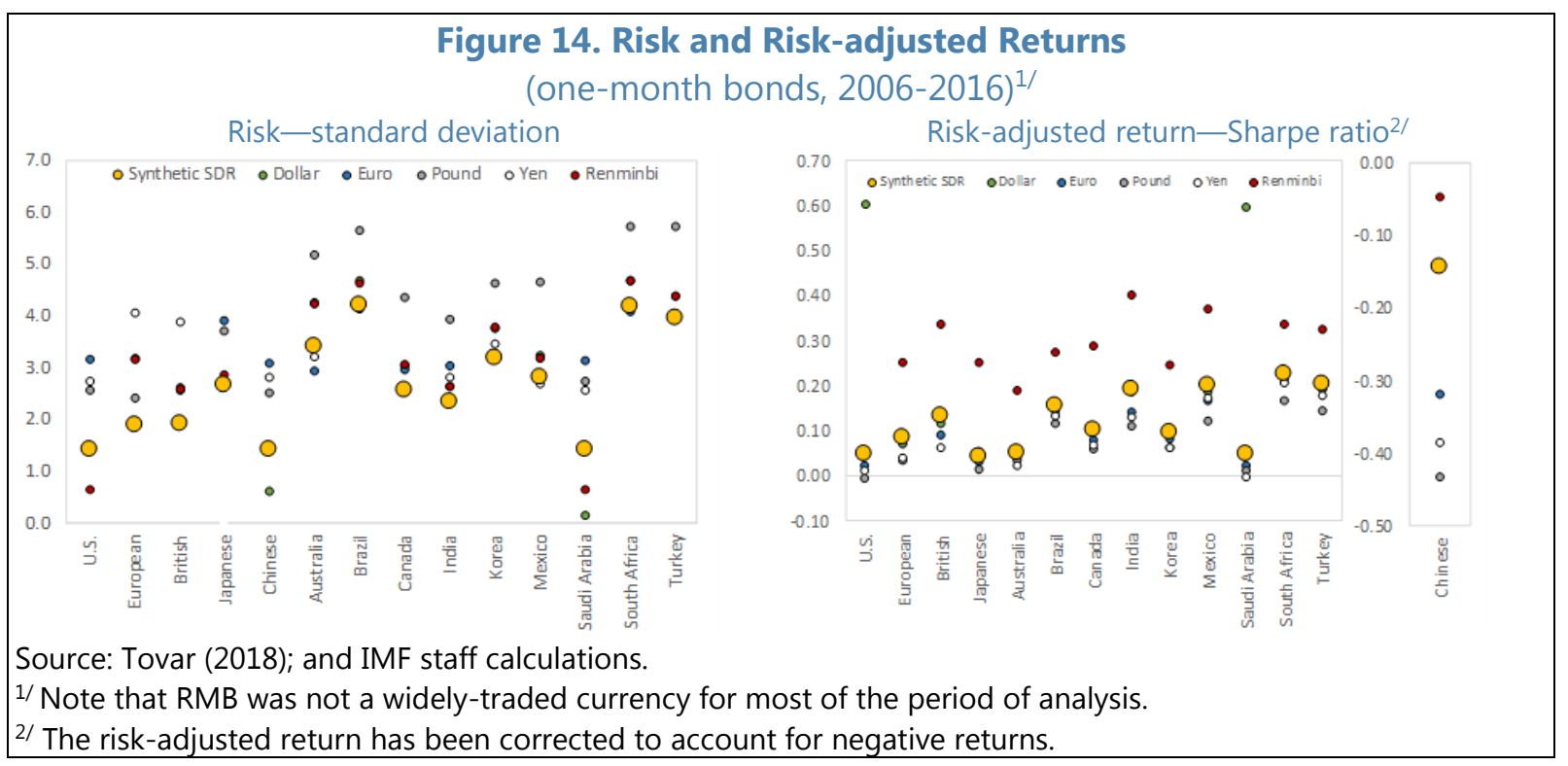

33. But M-SDR currency weights may not be optimal for most users. SDR basket weights broadly reflect the existing pattern of international currency use and exposure on aggregate (Table 1). This could make M-SDRs a convenient currency diversification instrument, providing efficiency and risk-reduction benefits for some participants in international transactions. The periodic reweighting of the basket may create a source of risk that is hard to model in the short term, but over the medium term has the advantage of stabilizing the M-SDR's value and keeping weights aligned with patterns of international currency use. Moreover, the M-SDR currently offers exposure to a currency subject to capital controls for private investors. ${ }^{28}$ However, M-SDRs offer only one of many potential sets of portfolio weights, regardless of the composition of the SDR basket. Market participants note that customized portfolios could achieve hedging needs better and relatively cheaply for many individual participants including firms and institutional investors.

34. Diversification benefits require an efficient M-SDR market. Deep, liquid markets facilitate efficient price discovery, liquidity, low transaction costs, and the availability of standardized derivatives, which reinforces use of the currency, creating network externalities and lock-in effects. Currently, only a few markets achieve these. In the currently limited M-SDR market, hedging and transaction costs outweigh the diversification benefits for most issuers and institutional investors. Market participants highlight that a liquidity premium would likely be required until market activity becomes sufficient to construct a benchmark yield-curve and undertake cross-currency swaps at desired maturities. For instance, despite benefitting from the movement toward European monetary integration, the ECU traded at a discount to its theoretical value for long periods (Dammers and McCauley, 2006). Even with regular issuance of high-quality instruments at sufficient volume, it would be challenging to identify a 'risk-free' benchmark.

\footnotetext{
${ }^{28}$ The RMB is subject to capital controls for private investors, although the M-SDR offers limited exposure to it and there is an active offshore RMB market. Agents taking counterpart positions may find it difficult to hedge against such a currency.
} 


\section{Using the U-SDR in trade invoicing and commodity pricing could provide greater stability of receipts and payments in domestic currency terms and enable more symmetric trade adjustment.}

- Commodity prices have been 7-15 percent less volatile in SDR terms than in U.S. dollars (Figure 15; see IMF, 2011b). This suggests that U-SDR pricing would modestly increase the stability of export receipts or import bills in domestic currency terms, although many firms can manage currency risk using financial instruments. Moreover, transaction costs would rise for issuers of dominant currencies.

- Use of the U-SDR, as opposed to a reserve currency, in trade invoicing by a large number of firms could reduce asymmetry in the short-run response of trade volumes to exchange rate movements. For instance, a depreciation against a reserve currency would improve price competitiveness of exports if they are priced in U-SDR rather than in the reserve currency. The resulting stronger export response could aid external adjustment for some countries. The benefits would be limited on a global scale since the SDR valuation already reflects the currency composition of trade invoicing (Table 1), although exporters and importers with concentrated currency invoicing weights that are not aligned with the geographic distribution of trade would gain.

\section{B. Could the SDR Help Fill Gaps in Official Provision of International} Liquidity?

\begin{tabular}{|l|l|l|}
\hline Form & Potential Impact & Drawback \\
\hline O-SDR & Could finance conditional lending & $\begin{array}{l}\text { Requires co-operation from reserve currency } \\
\text { issuers or many large members }\end{array}$ \\
\hline $\begin{array}{l}\text { M-SDR } \\
\text { U-SDR }\end{array}$ & $\begin{array}{l}\text { Wider use modestly increases } \\
\text { access to international financing }\end{array}$ & $\begin{array}{l}\text { Limited value added if SDR basket matches } \\
\text { existing reserve currency weights in } \\
\text { international transactions }\end{array}$ \\
\hline
\end{tabular}

\section{Potential gaps in the Fund's lending capacity could be filled by using O-SDRs as a} source of finance. The primary source of Fund resources are quota subscriptions, which, together with borrowing from official sources, have served the Fund well for decades. These avenues should be considered first when discussing adequacy of Fund resources and lending capacity. However, there could be a potential need for new instruments, for instance a standing facility to respond to 
unforeseen, large-scale events (IMF, 2016b). ${ }^{29}$ Such a standing facility could secure large, predictable access on a precautionary basis to countries satisfying ex ante criteria. ${ }^{30} 31$ One option for such a facility could be for O-SDRs to be allocated in exchange for newly-issued reserve currencies, making the outside supply of reserve currencies elastic in a crisis (Obstfeld, 2011). However, such fundamental changes would require amendment of the AoAs, and commitments from reserve currency issuers to exchange SDRs for their currency. ${ }^{32}$ Key design issues for the funding of such a facility on the basis of a redesigned O-SDR include: the allocation of credit risk associated with such large scale precautionary access; the mechanism for covering expected losses; the safeguards needed to ensure the proper functioning of the VTAs; the encashability of the committed resources to be considered part of reserve assets; and the bearer of the SDR interest cost. ${ }^{33}$

37. A trust pooling O-SDRs could provide an alternative source of finance. Countries that rarely intervene in foreign exchange markets could pool their SDR holdings in a trust that could provide financing to countries according to the mandate of the trust facility. This mechanism would be akin to the SDR loans provided by some members to the Poverty Reduction and Growth Trust (PRGT) and is feasible under the current AoAs. The credit risk in such a scheme would lie with the contributors to the pool. If the pool were a Fund-administered account or trust (held on behalf of the trust by a prescribed holder as in the case of the PRGT), the credit risk would still remain with creditors, but could potentially be mitigated if a reserve account were established to provide a buffer, although this would require agreement on the funding of such a buffer. The other operational considerations discussed in the paragraph above would also be relevant for the trust scheme. To secure sufficient resources, the trust could issue securities (e.g., M-SDRs) or the pool could be expanded by additional O-SDR allocations. ${ }^{34}$ Contrary to the proposal to exchange O-SDRs for reserve currencies discussed above, the trust would have moderate lending capacity, unless supported by large SDR allocations and high leverage.

\section{The impact of the M-SDR and U-SDR on the demand for official provision of} international liquidity would be modest. To the extent that widespread use of M-SDRs and USDRs lowers the sensitivity of capital and trade flows and the overall exposure of economies to policies in any single reserve-issuing economy, it could translate to more stable access to

\footnotetext{
${ }^{29}$ A financing gap could emerge under a severe, widespread shock, given current access levels. The GFC illustrates the potential scale of financing requirements in such a scenario where bilateral swap lines from reserve currency issuers played a large role (IMF, 2011e).

${ }^{30}$ A standing facility is distinct from the liquidity facility recently discussed (IMF, 2017d). The standing facility would be used for large-scale BOP needs arising from systemic events while the liquidity facility was intended to cover BOP needs arising from shocks of moderate size, which result from volatility in international markets and would not require additional Fund resources. The liquidity facility envisaged repeated drawings. Using the O-SDRs to finance a liquidity instrument would potentially encounter objections similar to those faced by the proposed liquidity facility.

31 Ocampo (2010), Truman (2008; 2011), Farhi and others (2011), Triffin International Foundation (2014), de Cecco and Giavazzi (1996); Boughton (2001), and Garritsen de Vries (1985a).

32 Such a facility might be preferable to bilateral swap lines by reserve currency issuers in as much as it might enhance systemic stability by providing a more predictable and multilateral approach in the context of a Fund policy instrument (Destais, 2014; Weder di Mauro and Zettelmeyer, 2017).

33 The operational details of such a facility are beyond the scope of this paper.

${ }^{34} \mathrm{~A}$ trust issuing securities was proposed for financing the response to climate change (Bredenkamp and Pattillo, 2010).
} 
international financing, reducing demand for official international liquidity provision. However, as noted above, the effects would be constrained by the high degree of correspondence between the weights in the SDR basket and the importance of the main reserve-issuing currencies in international transactions.

\section{Could the SDR Help Mitigate the Systemic Side Effects of Reserve} Accumulation?

\begin{tabular}{|l|l|l|}
\hline Form & Potential Impact & Drawback \\
\hline O-SDR & $\begin{array}{l}\text { Could substitute for precautionary } \\
\text { reserves }\end{array}$ & $\begin{array}{l}\text { Requires co-operation from reserve currency } \\
\text { issuers or many large members }\end{array}$ \\
\hline M-SDR & $\begin{array}{l}\text { Stability could reduce precautionary } \\
\text { demand and increase safe asset } \\
\text { supply }\end{array}$ & $\begin{array}{l}\text { Limited value-added as SDR basket } \\
\text { corresponds to existing reserve currency } \\
\text { weights in international transactions } \\
\text { Issuers limit safe-asset supply }\end{array}$ \\
\hline U-SDR & $\begin{array}{l}\text { Stability could reduce precautionary } \\
\text { demand }\end{array}$ & $\ldots .$. \\
\hline
\end{tabular}

\section{The O-SDR could reduce the side} effects from precautionary reserve accumulation. Slowing down reserve accumulation would require O-SDRs to be held as substitutes for other reserves, suggesting that the impact would be limited to reserves held for precautionary motives. ${ }^{35}$ Illustrative calculations applying the IMF's reserve adequacy metric (IMF, 2011d; 2015c) suggest that precautionary motives have indeed played a substantial role in reserve accumulation: non-precautionary reserves now account for roughly one-quarter of the global total, falling from more than a third in 2011 (Figure 16). ${ }^{36}$ Furthermore, if O-SDRs helped expand coverage of precautionary facilities, the need for precautionary reserves could be reduced. As discussed earlier, large scale additional allocations could necessitate co-operation to facilitate exchange between O-SDRs and reserve currencies.

\footnotetext{
35 O-SDRs would not substitute for reserves accumulated for purposes of maintaining exchange rate competitiveness for export-led growth because the O-SDRs would not affect the exchange rate in the same way that foreign exchange intervention would. Similarly, O-SDRs would be unlikely to substitute for commodity or intergenerational savings funds included in reserve holdings, which, unlike the O-SDRs, provide an endowment with a future stream of net income.
}

${ }^{36}$ Results at the individual country level are in line with those in IMF (2016i) and empirical work using alternative metrics (Obstfeld and others, 2010; Ghosh and others, 2014). 
40. The M-SDR could impact the IMS by diversifying the composition of reserve-related assets. As noted earlier, currency diversification of reserve-related assets (with corresponding effects on liabilities) could reduce current account imbalances, lower external balance sheet risks, and promote more efficient consumption and investment. The M-SDR could help achieve this. For example, if the currency composition reflected the SDR basket weights (and under the assumption that M-SDRs were widely used in international financial activity), the EBA model suggests that the U.S. current account norm would increase by 1.0 percent of GDP (Figure 17). The current account norms of other reserve currency issuers would be lower under this scenario, reflecting the hypothetical increase in the shares of their liabilities in international reserves. Furthermore, greater use of the SDR could lead to a broader distribution of seigniorage benefits.

41. But any impact on the global supply of safe assets would likely be small. Greater net availability of safe reserve assets, including SDR-denominated assets, would require borrowers of a high credit quality to shift issuance from non-reserve currencies (presumably their own) to M-SDRs without undermining the quality of their assets due to the added exchange rate risk. ${ }^{37}$ However, the incentive for such a shift seems limited, and the volumes of such issues are modest. Hence, the overall impact of M-SDRs on the global supply of safe assets would likely be small.

\section{COULD THERE BE COMPLEMENTARITIES FROM} USE OF THE SDR IN MULTIPLE CONCEPTUAL FORMS?

42. An ecosystem may be required to generate network externalities and attract a large share of transactions. The national currencies that play international roles do so across a wide spectrum of activity - as means of payment, unit of account, and store of value - supported by their depth, liquidity and network externalities. Achieving these conditions is a key challenge for the MSDR and U-SDR to reduce the costs of uptake relative to their potential benefits. However, there are potential complementarities between these two concepts and scope for the O-SDR and official support to provide a more supportive environment which could help reduce overall costs.

43. M-SDRs and U-SDRs could be mutually re-enforcing. Increased prevalence of U-SDRdenominated transactions could be financed or hedged using M-SDRs, which would increase M-SDR liquidity and reduce transactions costs. Greater M-SDR use might encourage agents to price transactions in U-SDRs. The ability to make secure payments in a stable unit of account would likely spur wider use of the M-SDR and U-SDR.

\footnotetext{
${ }^{37}$ For the same quality borrower, a switch from issuance in existing reserve currencies to M-SDR could indeed enhance the "safety" of the instruments due to the diversification properties of the M-SDR.
} 


\section{Market scale and liquidity would be critical for a self-perpetuating uptake of the M-}

SDR. A stable and substantial base of issuers and investors will likely be required to bring down the costs of using M-SDR instruments and to eliminate any illiquidity premium. Market participants emphasized the importance of a benchmark yield curve-particularly at the short-end-for pricing instruments through regular issuance of high-quality instruments. Cross-country data on sovereign debt show a negative relationship between the amount of outstanding debt and bid-ask spreads, an indicator of the liquidity risk premium (Figure 18). Preliminary staff analysis suggests a market size of $\$ 100$ billion could sustain a liquid debt securities market and accompanying derivatives market. Exchange Traded Funds (ETFs) are popular and conducive to replicating the SDR by holding its constituent currencies. Depending on investor demand, they could subsequently promote the SDR bond market by holding M-SDR instruments.

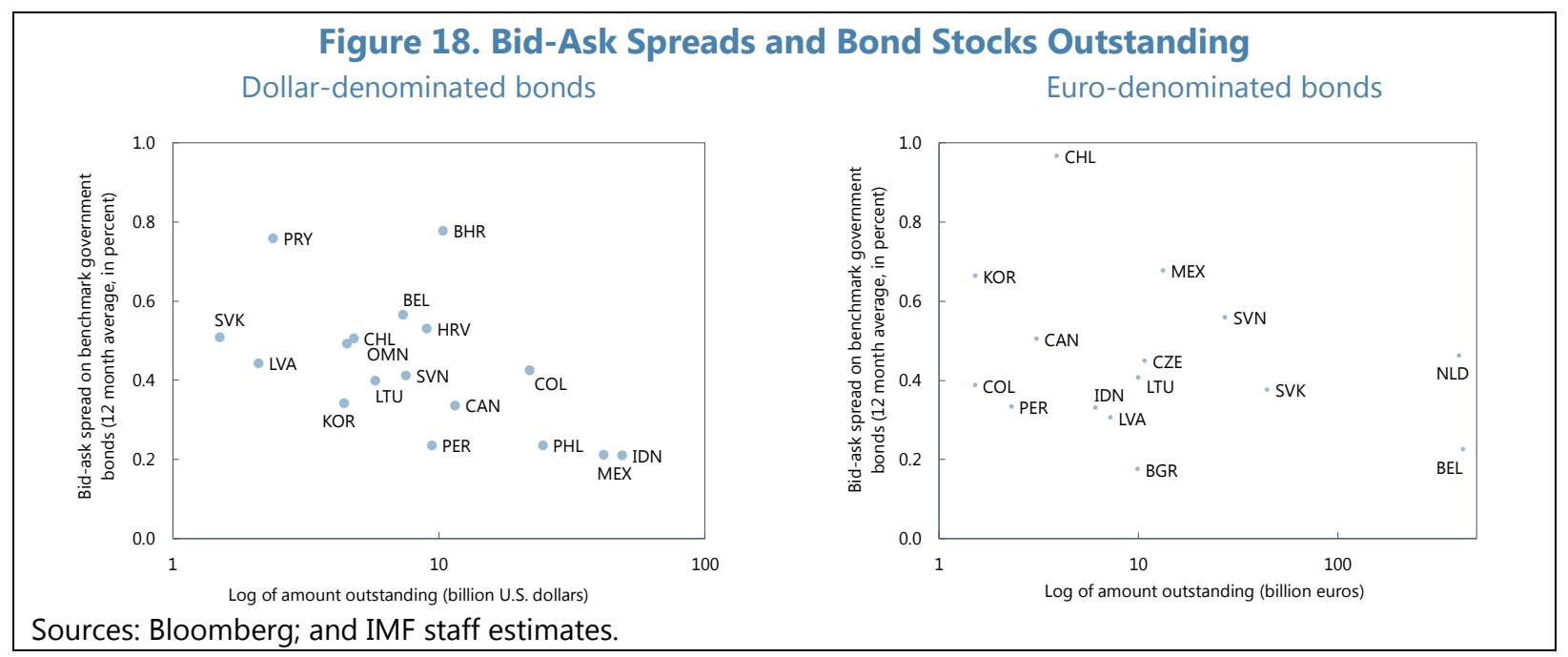

45. The M-SDR would need to overcome market infrastructure, settlement, and revision risk challenges. Providing continual pricing of the O-SDR against main global currencies and increasing the frequency of O-SDR interest rate resets (currently weekly) would facilitate pricing $\mathrm{M}$ SDRs and marking holdings to market. The composition and weighting of the SDR basket are subject to periodic revisions by the IMF's Executive Board. Large, unexpected revisions could have a significant impact on the SDR's valuation and its properties. However, most changes to the basket have been small and the risk can be modeled..$^{38}$ Widespread use of M-SDRs would likely require the development of M-SDR accounts such that transactions are settled directly in SDRs (Coats, 1982). Until then, M-SDRs would need to be settled in a currency, which would create an additional step in transactions and leave participants exposed to these currencies. ${ }^{39}$ In addition to settlement infrastructure and legal certainty in a well-regarded jurisdiction, there would be a need to set up clearing arrangements and develop market segments (e.g., derivatives and money markets).

\footnotetext{
38 Market participants understood the importance of retaining a role for the Board's judgment over the SDR basket, but felt that more transparency in determining currency inclusion and weights could make changes more predictable.

39 For example, recent M-SDRs issued in China specify settlement in RMB. Settlement in other currencies in other jurisdictions may pose currency risks due to the limited convertibility of the RMB.
} 


\section{Box 4. How Might Official Sector Support Encourage M-SDR Activity?}

Official sector support to help overcome threshold effects could include the following initiatives:

- A regular program of M-SDR bond issuance by multilateral development banks (MDBs) or sovereigns. This could help establish benchmarks for pricing SDR-denominated securities that could be issued by the private sector. Substantial issuance would enable the inclusion of SDR instruments in bond market indices, which in turn would encourage demand from institutional investors. MDBs that already engage in market issuance may be attracted to issue M-SDRs to manage currency risks and portfolio adjustment, although they already have the ability to fully hedge exposures. MDBs could also denominate part of their lending (likely involving a premium) in SDRs. Overall, official sector support would impose additional costs on their operations, at least initially.

- M-SDR bond issuance by the IMF. Such issuance would help develop the market and provide resources for IMF lending (IMF, 2011b). Issuance in large enough amounts to form a benchmark yield curve during normal times, when demand for use of IMF resources is low, would likely require amending the AoAs and fundamentally alter the financing model of the IMF, raising major policy and regulatory issues. ${ }^{1}$

- Providing liquidity backstop facilities for the market. Central banks could provide a repo facility for investors to pledge their M-SDR assets in exchange for short-term liquidity in convertible currencies (provided the instruments meet other requirements such as credit risk). O-SDRs, rather than convertible currencies, could be provided by central banks, although such a step would require amending the AoAs to permit the private sector to hold O-SDRs. M-SDR bonds could also include put options, which would give the investor the right to sell the security back to the issuer at a predetermined price. Official institutions could also offer instruments in currency and interest swap markets to facilitate liquidity.

- Clarifying regulatory issues and promoting the development of other elements of market infrastructure. The demand for M-SDRs will crucially depend on their regulatory treatment, e.g. how banks' reserve requirements on SDR-denominated deposits are calculated and constituted, or whether M-SDR instruments are liquid enough to qualify as high-quality liquid assets under the Basel III liquidity coverage ratio.

${ }^{1 /}$ As discussed above, such issuance could be conducted by a trust in which members pool existing O-SDR holdings and augment resources with M-SDR issuance for on-lending.

\section{Official sector support could offset transaction costs and develop market} infrastructure, though uptake may still be hard to achieve (Box 4). Given network externalities, official support may be needed to help the M-SDR overcome threshold effects. Official sector actions-including by potential "first-mover" issuers, regulatory authorities, and official providers of market liquidity-could be conducive to market development and spur private initiatives to develop other necessary elements of the market ecosystem. Support is not without its own challenges and may not be sufficient to make M-SDRs a better value proposition than customized or hedged currency portfolios.

47. The U-SDR would also face impediments. A clearance/payments system would be needed to settle SDR claims cost-effectively. This would also avoid having final settlement undertaken in currencies, which would expose parties in the transaction to currency risk. Uncertainty on the 
outcome of SDR reviews could affect the SDR's attractiveness as a unit of account, though the impact of basket revisions on the SDR's longer-term value has generally been modest, allowing the SDR to act as a stable measure (IMF, 2016g). Also, demand for data reporting is currently limited. Publishing statistics denominated in SDRs could smooth (but not fully remove) valuation changes from fluctuations among major currencies. In a survey, national data compilers generally did not see significant demand for SDR-denominated statistics, while the appetite of data users was limited. This highlights that broad take-up of the U-SDR would have to overcome network effects/switching costs.

\section{THE SDR IN THE FUTURE IMS}

48. Economic and technological developments create uncertainties about the future shape of the IMS and might increase or decrease the merits of the SDR. The global economy is becoming more multipolar, with the potential for shifts in the demand for, and supply of, reserve assets. Yet the pace of such shifts is subject to uncertainty, which is amplified by new financial and other technologies as well as policy choices. This section aims to initiate a discussion on risks to the IMS from multipolarity and financial innovations such as DLTs, which may have implications for the economic role of the various SDR concepts. Both topics are subject to high uncertainty, go beyond the scope of this paper-as they are broader than the SDR-, and deserve further scrutiny.

\section{A. Uncertain Economic Transitions}

49. Shifting economic weights raise the prospect of a more multipolar global economy. Rapid financial and economic integration of EMDEs are driving convergence and creating more potential sources of global economic influence, which would create a more multipolar global economy. However, the timing of these trends is hard to predict given uncertainties around support for and policy reactions to global economic integration as well as inherent difficulties in anticipating the impact on integration from the pace of technological change.

50. It is uncertain how international currency use would change. ${ }^{40} 41$ Growth in demand for reserves might outpace growth in the liquid liabilities of a small number of $A E$ issuers who represent a shrinking portion of the global economy. However, EMDEs may not require additional foreign exchange reserves as they grow, as their own financial markets develop, and as their exchange rate flexibility increases (Bordo and McCauley, 2017). On the supply side, it is unclear when alternative sources of "safe assets" will emerge, or where. Economic heft is not enough: financial market development, institutional reforms, and geopolitical factors also matter. Network effects and inertia due to habit formation could slow down the impact of multipolarity trends on the international use of currencies. But new evidence suggests network effects may be weaker than previously believed

\footnotetext{
40 The global financial system has experienced periods during which multiple currencies played a leading role, such as before 1914 and between the two world wars, though the extent of financial integration-and thus the effects of reserve-issuing status-was much lower in those eras (Lindert, 1969; Eichengreen, 2014). The subsequent transition away from reserve multipolarity (Singleton and Schenk, 2015) increased the influence of policies at the center.

${ }^{41}$ Figure 8 suggests the relative importance of the major anchor currencies has been changing. Tovar and Mohd Nor (2018) provide some evidence of increasing Chinese renminbi influence, although no further gains have been observed since 2012.
} 
and are declining due to technological advances; this could support a quicker transition (Eichengreen, Mehl and Chitu, 2017).

51. Transition risks to the IMS may be significant. Uncertainties about how the supply and demand for reserves will evolve highlight the systemic risk of insufficient liquidity or a deterioration in the quality of "safe assets." If inertial forces prove limited, this could result in rapid and volatile changes in currency composition of reserve assets. Yet if they prove strong, concerns associated with the Triffin dilemma over the sustainability of continued accumulation of claims on a limited set of assets could eventually become acute, which could risk an even more disorderly shift. Moreover, network effects imply that, once pressures build to overcome strong inertia, the shift of safe asset holdings to new issuers could be substantial and cause disruptive movements in exchange rates and capital flows. Moreover, in times of global stress there could be uncertainty as to whether there would be one preferred source of global liquidity (as during the GFC), multiple lenders of last resort either co-operating globally or acting within their regional spheres of influence, or insufficient liquidity in a globally fragmented system. Such uncertainty could be exacerbated by geopolitical developments.

\section{There is also no consensus as to whether a multipolar reserve system would be more} stable than a unipolar one. After a transition period, the availability of multiple reserve issuers might facilitate supply while incentivizing policy discipline in each issuer and giving greater need for international policy coordination. However, whether these effects would materialize depends on IMS characteristics such as relative sizes of currency issuers, relative scarcity of reserve assets, the system of exchange rates, commitment to low inflation and other macroeconomic characteristics, as well as how they influence the supply of reserves by currency issuers (Farhi and Maggiori, 2016; He and others, 2016). ${ }^{42}$ With more reserve issuers, the system could also be potentially exposed to more frequent and pronounced portfolio shifts. ${ }^{43}$

\section{An SDR-denominated substitution account could support the transition to a more} multipolar IMS, but would face serious obstacles. Proposals for a substitution account were debated in the 1970s and early 1980s, and the idea has resurfaced since the GFC. Holdings of foreign exchange would be placed in an IMF-administered account in return for SDR-denominated claims. The account would in turn hold long-term claims on reserve currency issuers (McCauley and Schenk, 2015; Boughton, 2001). This would diversify the currency composition of reserve holdings in off-market transactions so as not to disrupt foreign exchange markets, given the potential large scale of shifts in their reserve portfolios. Furthermore, if the claims on the account were tradable, they could support M-SDR activity. At the same time, a substitution account could be subject to sizeable foreign exchange risks, especially if there were to be large and un-hedged swings in the underlying exchange rate exposures. Moreover, the account's asset holdings could potentially be subject to credit risks. Past discussions of such an account came to an impasse over who would bear the potential costs associated with exchange rate and interest rate risk in the account - issues that

\footnotetext{
42 For example, if issuers cannot commit to not inflating away debts, worsening coordination problems might reduce the supply of reserve assets and reduce the stability of the IMS.

43 This phenomenon was first highlighted for the interwar period, and related to shifts between the British pound and U.S. dollar (Nurkse, 1944).
} 
could be even more pronounced in the transition to a more multipolar system as some currencies in the account depreciate over time against the O-SDR. ${ }^{44}$

54. Increasing multipolarity could magnify potential benefits of the SDR. Systemic risk posed by the Triffin dilemma would magnify the benefits of O-SDRs by potentially lowering precautionary reserve accumulation and reducing pressure on the BOP of existing and emerging reserve issuers. Higher potential demand for precautionary instruments could also strengthen interest in use of the O-SDR as a financing instrument. If the transition toward a multipolar system is more volatile, the M-SDR could enhance stability by facilitating a shift to holdings in multiple currencies with reduced volatility in demand for any particular currency. ${ }^{45}$ Similarly, if currency fluctuations were to become more pronounced in such an environment, the U-SDR could provide a more stable common standard for transactions.

\section{A radically reformed SDR could conceivably serve as a global currency. A radical} redesign of the IMS could introduce the SDR as genuine new currency-an "outside" money. The design of such a system is beyond the scope of this paper, but consideration would need to be given to issuance rules or modalities, such as the appropriate balance between rules and discretion and how elastic supply would be. For example, issuance could be limited to episodes of global stress (improving global liquidity provision). The SDR could alternatively have a broader role as a global risk-free asset such that the issuer's possibly discretionary supply function aims to manage global liquidity beyond acute situations (thus reducing demand for traditional reserve currencies) or possibly in trade (facilitating more symmetric external adjustment). The range of users could vary: recipients could be limited to current prescribed holders, expanded to include private systemicallyimportant global institutions or platforms, or made universally accessible. ${ }^{46}$ To help establish credibility and stability, the currency could potentially be backed by the membership of the institution issuing the currency or by the institution's own assets, though other options would need to be explored.

\section{There would be many practical and economic limits to the reach of the SDR. A key} question is to what extent the backing available would be a binding constraint to the quantity of SDR issuance. Extending the uses and users of the SDR would require changes to the AoAs, and it is not even clear whether widespread use would be desirable. For example, backing the SDR carries exchange rate and interest rate risks ultimately borne by fiscal authorities, while individual countries' public debt sustainability could be influenced by the extent of SDR liquidity provision. Furthermore, unless the world moves closer to an optimal currency area, "SDR-ization" could reduce monetary policy autonomy for individual countries and render exchange rate adjustment less effective. While this would present similar problems to those currently faced by countries constrained by U.S.

\footnotetext{
${ }^{44}$ If the account accepted deposits at any time, participants could deposit assets denominated in currencies that were expected to depreciate in the short term, exposing the account to potential valuation losses.

45 Some investors with long horizons may already view the M-SDR as a way to reduce uncertainties presented by a multipolar future since other hedges may not be as suitable over long time spans.

46 Some central banks are reconsidering offering universal access by offering direct deposit accounts to the public (Bordo and Levin, 2017; Bech and Garrat, 2017). Universal access could similarly entail allowing anyone to make deposits directly with, for example, the IMF in one of the reserve currencies in exchange for an account denominated in SDRs and redeemable in any of its constituent currencies.
} 
monetary policy, it has the advantage that the policy rule for SDR issuance could be more responsive to the global cyclical position rather than that of one country.

\section{B. Cryptocurrencies and Distributed Ledger Technologies}

\section{Technological innovation in the financial sector could affect cross-border}

transactions. Many fintech innovations have the potential to alter the financial sector landscape (He and others, 2016; He and others, 2017). For instance, DLTs (Box 5) can be applied to various processes in cross-border payments, lowering back-office and compliance costs and potentially boosting international financial flows. While DLT-based solutions could potentially offer significant savings, they currently require conversion of fiat money to electronic 'tokens' for payments. Cryptocurrencies could facilitate the transformation of cross-border payments toward DLT-based systems. Cryptocurrencies issued by central banks (CBCCs) might be more trusted and potentially address some shortcomings of private cryptocurrencies, ${ }^{47}$ for example by providing a stable link to fiat money.

\section{Although technological outcomes are very difficult to predict, such innovations might} influence the IMS and alter the assessment of the role of the SDR. For example, more efficient payment systems could overcome inertial forces that support incumbent currencies, potentially speeding up transitions between existing and any new reserve assets. Alternatively, if technological change makes economies of scale less important, this might increase the number of reserve currencies the IMS can accommodate, with a possible shift toward currencies with better payment platforms. Fintech and DLTs could also boost interconnectedness, aggravating susceptibility to spillovers and swings in capital flows (amid financial stability concerns brought about by other fintech developments). Therefore, fintech and DLTs could amplify the weaknesses of the IMS discussed earlier and change assessments on the role of the SDR.

\footnotetext{
47 He and others (2016) argue that, in their current form, cryptocurrencies' high price volatility curtails their reliability as a store of value, that their small acceptance network restricts their use as a medium of exchange, and that there is limited evidence of their use as a unit of account independent of fiat money.
} 


\section{Box 5. Distributed Ledger Technologies and Cryptocurrencies}

DLTs provide the platforms for cryptocurrencies and promise a range of other improvements in commerce, yet introduce risks. They present challenges and opportunities for central banks.

DLTs underpin cryptocurrencies, one of many types of Virtual Currency (VC). VCs are digital representations of value, issued by private developers and denominated in their own unit of account (rather than in any existing fiat currency). Among various types of VCs, decentralized VCs (referred to as cryptocurrencies) have recently gained prominence. They rely on DLTs and use techniques from cryptography for payment processing, with participants typically rewarded in newly minted 'currency' for verifying and validating transactions. DLTs are the protocols and infrastructure that allow computers to validate transactions and update records in a synchronized way across a network. Distributed databases maintained by a master administrator and duplicated across a network are not new, but DLT systems can function without a centralized authority. Blockchain is one form of DLT and powers the Bitcoin network and cryptocurrency, whose market capitalization exceeds half of all cryptocurrencies. ${ }^{1}$ Bitcoin's use as a medium of exchange has grown rapidly, but its value has been volatile, questioning its success as a medium of exchange or store of value.

\section{Box 5. Distributed Ledger Technologies and Cryptocurrencies (concluded)}

Private cryptocurrencies present challenges to financial stability and macroeconomic management. Private cryptocurrencies could complicate functioning of central banks by creating an alternative to official fiat money and thus eroding the monetary base. They pose unknown risks to financial stability, especially in times of stress, given their short track record, lack of public sector backing, and large swings in valuation on account of unknown and in some cases rigid supply rules. DLTs might make circumventing exchange or capital controls easier (further complicating attempts to manage the economy in the event of shocks). Given their pseudo-anonymous nature, private cryptocurrencies can also serve as a vehicle for money laundering and terrorist financing. These risks may be modest unless private cryptocurrencies and more generally DLTs become widespread (He and others, 2016).

DLTs can enable other institutional improvements affecting cross-border flows. Smart contracts, whose terms are executed by a computer, might enable parties to trade internationally without intermediaries and with reduced risks of noncompliance, delay, or default. DLTs could also boost trade by improving information (like tariff codes, credit history, and sanitary certificates). Technology startups already offer cross-border payments that include exchanges between Bitcoin and local currencies. He and others (2017) discuss how a DLT-based hub-and-spoke payments network could become an efficient alternative to the traditional system based on correspondence banking. DLTs might promote financial inclusion by lowering the execution and compliance costs of remittances, while a consortium is building a DLT platform for trade finance aimed at small businesses.

\section{Central banks are investigating if central bank cryptocurrencies (CBCC) could improve their functions (He and others, 2017).}

- For domestic payments systems, the Bank of Canada conducted an exercise where a limited number of wholesale market participants pledge cash in exchange for a CBDC (Cad-Coin) redeemable at par, while the Monetary Authority of Singapore introduced SGD-on-ledger for the interbank market (MAS, 2017). However, some have questioned whether touted improvements in monetary operations would be worth the additional expenditure and risk relative to other 
technological investments, for example in real-time payments systems (Quarles, 2017; Engert and Fung, 2017).

- If issued for broader retail banking, CBCCs may expand the monetary policy toolkit because they would be part of the monetary base and, like reserves and unlike cash, can have (possibly negative) interest rates. However, central banks could alternatively consider issuing digital currency through publicly available accounts (as done in Ecuador) rather than as tokens using DLTs (Bordo and Levin, 2017). The Bank of Sweden is yet to make its choice for the eKrona.

- DLTs might streamline regional cross-border interbank systems that facilitate payment in regional or local currencies, as considered in a pilot by the Central Bank of Brazil and some of its neighbors (Burgos, Filho, Suares, and Almeida, 2017). This could be a step toward widespread use of DLTs or specifically CBCCs for cross-border commerce.

1/ At end-December 2017, cryptocurrencies' market capitalization was approximately $\$ 600$ billion (Bitcoin's share exceeded one third and was approximately double M0 in the United Kingdom). At the start of 2017, market capitalization was less than $\$ 20$ billion, reflecting explosive yet volatile growth in many cryptocurrency prices throughout the year. By one estimate, the number of daily transactions was approximately $1 \frac{1 / 2}{2}$ million and is well short of the approximately 7 million mobile payments using M-pesa (Bech and Garrat, 2017; bitinfocharts.com; coinmarketcap.com; https://coinmetrics.io/charts/).

\section{New technologies could help kick start broader adoption of the SDR if more} fundamental challenges facing the SDR can be overcome. While the use of the SDR is currently constrained by political and economic challenges rather than by technology, more work is needed to assess how fintech could help to overcome initial market development. For example, could basing the M-SDR on an alternative payment or settlement system that does not require scale economies help the M-SDR overcome illiquidity and other constraints? ${ }^{48}$ Or, if the SDR were to serve as a global currency-along the lines of a radically transformed role of the SDR discussed in paragraph 55what additional benefits might derive from an O-SDR issued as a digital token? How might a DLTbased payments system affect the relationship between CBCCs and a digital SDR?

\section{ISSUES FOR DISCUSSION}

\section{Directors may wish to address the following questions:}

- Do Directors see a potentially meaningful role for the O-SDR in addressing identified gaps in the IMS and the GFSN? If so, what avenues for expanding the role of the O-SDR would Directors find most promising? How do Directors assess the concerns related to moral hazard and targeting SDR allocations to countries with more liquidity constraints?

- Do Directors see a role for the M-SDR in aiding external adjustment and reducing excess reserve accumulation? Can the technical and institutional challenges highlighted in the paper be overcome with official support?

- Do Directors see a case for a supporting role for the U-SDR?

\footnotetext{
${ }^{48}$ Market participants may also see opportunity in exploiting the relative stability and neutrality of the SDR by offering private cryptocurrencies linked to the SDR. There are already cryptocurrencies with purported yet tenuous links to the SDR. The IMF has not trademarked the SDR, and does not comment on such initiatives.
} 
- Do Directors see merit in broader work on how economic and technological developments can shape the IMS, including the role of the SDR in the IMS in light of these developments? 


\section{References}

Abbate, Angela, Sandra Eickmeier, Wolfgang Lemke, and Massimiliano Marcellino, 2016, "The Changing International Transmission of Financial Shocks: Evidence from a Classical TimeVarying FAVAR," Journal of Money, Credit, and Banking 48: 573-601.

Agosin, Manuel, and Franklin Huaita, 2012, "Overreaction in capital flows to emerging markets: Booms and sudden stops," Journal of International Money and Finance 31: 1140-1155.

Ahmed, Shaghil, and Andrei Zlate, 2014, "Capital flows to emerging market economies: A brave new world?" Journal of International Money and Finance 48: 221-248.

Ahmed, Swarnali, Maximiliano Appendino, and Michele Ruta, 2017, "Global Value Chains and the Exchange Rate Elasticity of Exports," The B.E. Journal of Macroeconomics 17: 1-24.

Aizenman, Joshua, 2013, "The impossible trinity-from the policy trilemma to the policy quadrilemma," Global Journal of Economics 2, March.

Aizenman, Joshua, Menzie Chinn, and Hiro Ito, 2016, "Monetary policy spillovers and the trilemma in the new normal: Periphery country sensitivity to core country conditions," Journal of International Money and Finance 68: 298-330.

Alfaro, Laura, Sebnem Kalemli-Ozcan, and Vadym Volosovych, 2014, "Sovereigns, Upstream Capital Flows, and Global Imbalances," Journal of the European Economic Association 12: 1240-1284.

Allen, Polly Reynolds, 1990, "The Private ECU Markets: What They Are, Why They Exist, and Where They May Go," Journal of Banking and Finance 14: 845-76.

Bayoumi, Tamim, Joseph Gagnon, and Christian Saborowski, 2015, "Official financial flows, capital mobility, and global imbalances," Journal of International Money and Finance 52: 146-174.

Bech, Morten and Rodney Garratt, 2017, "Central bank cryptocurrencies," BIS Quarterly Review, September.

Behar, Alberto, and Armand Fouejieu, 2017, "External adjustment in oil exporters: The role of fiscal policy and the exchange rate," World Economy.

Berkmen, S. Pelin, Gaston Gelos, Robert Rennhack, and James Walsh, 2012, "The GFC: Explaining cross-country differences in the output impact," Journal of International Money and Finance 31: 42-59.

Bini Smaghi, Lorenzo, 2011, "The Triffin dilemma revisited," Speech at the Conference on the International Monetary System: Sustainability and Reform Proposals, October 3.

Bordo, Michael, and Andrew Levin, 2017, "Central Bank Digital Currency and the Future of Monetary Policy," NBER Working Paper No. 23711.

Bordo, Michael, and Robert McCauley, 2017, "Triffin: dilemma or myth?" BIS Working Paper No. 684.

Borio, Claudio, Harold James, and Hyun Song Shin, 2014, "The international monetary and financial system: a capital account historical perspective," BIS Working Paper No. 457. 
Borio, Claudio, Robert McCauley, and Patrick McGuire, 2011, "Global credit and domestic credit booms," BIS Quarterly Review, September.

Boughton, James, 2001, Silent Revolution, The International Monetary Fund, 1979-1989, Washington, D.C.: IMF.

Bredenkamp, Hugh, and Catherine Pattillo, 2010, "Financing the Response to Climate Change," IMF Staff Position Note SPN/10/06.

Burgos, Adenio, Jose Filho, Marcus Suares, and Rafael Almeida, 2017, "Distributed ledger technical research in Central Bank of Brazil," Banco Central Do Brasil.

Caballero, Ricardo, and Emmanuel Farhi, 2014, "On the role of safe asset shortages in secular stagnation," in Coen Teulings and Richard Baldwin, editors, Secular Stagnation: Facts, Causes and Cures, A VoxEU eBook, London: CEPR Press.

Caballero, Ricardo, Emmanuel Farhi, and Pierre-Olivier Gourinchas, 2016, "Global Imbalances and Currency Wars at the ZLB," NBER Working Paper No. 21670.

Calvo, Guillermo, Alejandro Izquierdo, and Luis-Fernando Mejía, 2008, "Systemic Sudden Stops: The Relevance of Balance-Sheet Effects and Financial Integration," NBER Working Paper No. 14026.

Casas, Camila, Federico Díez, Gita Gopinath, and Pierre-Olivier Gourinchas, 2016, "Dominant Currency Paradigm: A New Model for Small Open Economies," NBER Working Paper No. 22943.

Cetorelli, Nicola, and Linda Goldberg, 2011, "Global Banks and International Shock Transmission: Evidence from the Crisis," IMF Economic Review 59: 41-76.

Chitu, Livia, 2016, "Reserve Accumulation, Inflation and Moral Hazard: Evidence from a Natural Experiment," European Central Bank Working Paper No. 1880.

Coats, Warren, 1982, "The SDR as a Means of Payment," IMF Staff Papers 29: 422-436.

Cravino, Javier, and Andrei Levchenko, 2017, "The Distributional Consequences of Large Devaluations," American Economic Review 107(11): 3477-3509.

Csonto, Balasz, and Camilo Tovar, 2017 "The Role of Uphill Capital Flows in the International Monetary System," IMF Working Paper WP17/174.

de Cecco, Marcello, and Francesco Giavazzi, 1996, "The Use of SDRs in the Financing of Official Safety Net Mechanisms," in Michael Mussa, James Boughton, and Peter Isard, editors, The Future of the SDR in Light of Changes in the International Financial System, Washington, D.C.: IMF.

Dammers, Clifford, and Robert McCauley, 2006, "Basket Weaving: The Euromarket Experience with Basket Currency Bonds," BIS Quarterly Review, March.

Destais, Christophe, 2014, "Central Bank Currency Swaps and the International Monetary System," Policy Brief No. 2014-05 (Paris, CEPII). 
Dooley, Michael, David Folkerts-Landau, and Peter Garber, 2003, "An Essay on the Revived Bretton Woods System," NBER Working Paper No. 9971.

Duval, Romain, Nan Li, Richa Saraf, and Dulani Seneviratne, 2016, "Value-added trade and business cycle synchronization," Journal of International Economics 99: 251-262.

Eichengreen, Barry, 2011, Exorbitant Privilege: The Rise and Fall of the Dollar and the Future of the International Monetary System, New York: Oxford University Press.

Eichengreen, Barry, 2014, "International Currencies Past, Present and Future: Two Views from Economic History," Bank of Korea Working Paper No. 2014-31.

Eichengreen, Barry, and Jeffrey Frankel, 1996, "Implications of the Future Evolution of the International Monetary System," in Michael Mussa, James Boughton, and Peter Isard, editors, The Future of the SDR in Light of Changes in the International Financial System, Washington, D.C.: IMF.

Engert, Walter, and Ben Fung, 2017, "Central Bank Digital Currency: Motivations and Implications," Bank of Canada Staff Discussion Paper 2017-16.

Farhi, Emmanuel, Pierre-Olivier Gourinchas, and Hélène Rey, 2011, Reforming the International Monetary System, London: CEPR Press.

Farhi, Emmanuel, and Matteo Maggiori, 2016, "A Model of the International Monetary System," NBER Working Paper No. 22295.

Forbes, Kristin, and Francis E. Warnock, 2012, "Capital flow waves: Surges, stops, flight, and retrenchment," International Journal of Economics 88: 235-251.

Frankel, Jeffrey, and Shang-Jin Wei, 1994, "Yen Bloc or Dollar Bloc? Exchange Rate Policies of the East Asian Economies," in Takatoshi Ito and Anne Krueger, editors, Macroeconomic Linkage: Savings, Exchange Rates, and Capital Flows, NBER-EASE Volume 3, Chicago: University of Chicago.

Gagnon, Joseph, 2013, "The Elephant Hiding in the Room: Currency Intervention and Trade Imbalances," Peterson Institute for International Economics Working Paper 13-2.

Garritsen de Vries, Margaret, 1976, The International Monetary Fund 1966-1971, The System Under Stress Volume II: Documents, Washington, D.C.: IMF.

Garritsen de Vries, Margaret, 1985a, The International Monetary Fund 1972-1978, Cooperation on Trial, Volume I: Narrative and Analysis, Washington, D.C.: IMF.

Garritsen de Vries, Margaret, 1985b, The International Monetary Fund 1972-1978, Cooperation on Trial, Volume II: Narrative and Analysis, Washington, D.C.: IMF.

Ghosh, Atish R., Jonathan D. Ostry, and Mahvash S. Qureshi, 2017, Taming the Tide of Capital Flows: A Policy Guide, Cambridge, MA: MIT Press.

Ghosh, Atish R., Jonathan D. Ostry, and Charalambos G. Tsangarides, 2014, "Accounting for emerging market countries' international reserves: Are Pacific Rim countries different?" Journal of International Money and Finance 49: 52-82. 
Goldberg, Linda, and Cédric Tille, 2008, "Vehicle Currency Use in International Trade," Journal of International Economics 76: 177-192.

Goldberg, Linda, and Cédric Tille, 2009, "Macroeconomic interdependence and the international role of the dollar," Journal of Monetary Economics 56: 990-1003.

Gopinath, Gita, 2015, "The International Price System," NBER Working Paper No. 21646.

Gourinchas, Pierre-Olivier, and Maurice Obstfeld, 2012, "Stories of the Twentieth Century for the Twenty-First," American Economic Journal: Macroeconomics 4: 226-265.

Hausman-Guil, Guillermo, Eric van Wincoop, and Gang Zhang, 2016, "The Great Recession: Divide between Integrated and Less Integrated Countries," IMF Economic Review 64: 135-176.

He, Dong, Karl Habermeier, Ross Leckow, Vikram Haksar, Yasmin Almeida, Mikari Kashima, Nadim Kyriakos-Saad, Hiroko Oura, Tahsin Saadi Sedik, Natalia Stetsenko, and Concepcion Verdugo-Yepes, 2016, Virtual Currencies and Beyond: Initial Considerations, IMF Staff Discussion Note SDN/16/03.

He, Dong, Ross Leckow, Vikram Haksar, Tommaso Mancini-Griffoli, Nigel Jenkinson, Mikari Kashima, Tanai Khiaonarong, Céline Rochon, and Hervé Tourpe, 2017, Fintech and Financial Services: Initial Considerations, IMF Staff Discussion Note SDN/17/05.

He, Zhiguo, Arvind Krishnamurthy, and Konstantin Milbrandt, 2016, "A Model of Safe Asset Determination," NBER Working Paper No. 22271.

Hirsch, Fred, 1971, "SDRs and the Working of the Gold Exchange Standard," IMF Staff Papers 18: 221-253.

Hoguet, George and Solomon Tadesse, 2011, "The role of SDR-denominated securities in official and private portfolios", in Portfolio and risk management for central banks and sovereign wealth funds, BIS Paper No. 58: 165-186.

Huang, Yiping, Daili Wang, and Gang Fan, 2014, "Paths to a Reserve Currency: Internationalization of the Renminbi and Its Implications," ADBI Working Paper No. 482.

Ilzetzki, Ethan, Carmen Reinhart, and Kenneth Rogoff, 2017, “Exchange Arrangements Entering the $21^{\text {st }}$ Century: Which Anchor Will Hold," NBER Working Paper No. 23134.

Imbs, Jean, 2006, "The real effects of financial integration," Journal of International Economics 68: 296-324.

Imbs, Jean, 2010, "The First Global Recession in Decades," IMF Economic Review 58: 327-354.

International Monetary Fund, 1968, Establishment of a Facility Based on Special Drawing Rights in the International Monetary Fund and Modifications in the Rules and Practices in the Fund, reprinted in Garritsen de Vries, Margaret, 1976, The International Monetary Fund 1966-1971, The System Under Stress, Volume II: Documents, Washington, D.C.: IMF. 1980, Special Drawing Rights Department - Abrogation of the Rules for Reconstitution, EBS/80/253, Washington, D.C.: IMF. 
2009a, Proposal for a General Allocation of SDRs, Washington, D.C.:

IMF.

2009b, Allocation of Special Drawing Rights for the Ninth Basic Period-

Draft Executive Board Decision Managing Director Report to the Board of Governors, Washington, D.C.: IMF.

Washington, D.C.: IMF.

2010a, Reserve Accumulation and International Monetary Stability,

2010b, The Fund's Mandate-Future Financing Role: Reform Proposals, Washington, D.C.: IMF.

2011a, Strengthening the International Monetary System-Taking Stock and Looking Ahead, Washington, D.C.: IMF.

2011b, Enhancing International Monetary Stability-A Role for the SDR?,

Washington, D.C.: IMF.

2011c, Criteria for Broadening the SDR Currency Basket, Washington,

D.C.: IMF.

,2011d, Assessing Reserve Adequacy, Washington, D.C.: IMF.

2011e, Analytics of Systemic Crises and the Role of Global Financial

Safety Nets, Washington, D.C.: IMF.

,2014, "Are Global Imbalances at a Turning Point?" Chapter 4 in World Economic Outlook, October, Washington, D.C.: IMF.

,2015a, Review of the Method of Valuation of the SDR, Washington, D.C.:

IMF.

2015b, "Measures which are Both Macroprudential and Capital Flow

Management Measures: IMF Approach," IMF staff note for G20, Washington, D.C.: IMF.

2015c, Assessing Reserve Adequacy—Specific Proposals, Washington,

D.C.: IMF.

2016a, Strengthening the International Monetary System-A

Stocktaking, Washington, D.C.: IMF.

,2016b, Adequacy of the Global Financial Safety Net, Washington, D.C.:

IMF.

2016c, Adequacy of the Global Financial Safety Net-Considerations for

Fund Toolkit Reform, Washington, D.C.: IMF.

,2016d, Report of the Managing Director to the Board of Governors and

the Executive Board Pursuant to Article XVIII, Section 4(c), Washington, D.C.: IMF.

2016e, The Case for a General Allocation of SDRs During the Eleventh

Basic Period, Washington, D.C.: IMF.

CInternational Monetary Fund. Not for Redistribution 
2016f, Staff Note for the G20: The Role of the SDR-Initial

Considerations, Washington, D.C.: IMF.

2016g, Capital Flows - Review of Experience with the Institutional View,

Washington, D.C.: IMF.

2016h, The Chairman's Summing Up: Adequacy of the Global Financial

Safety Net-Considerations for Fund Toolkit Reform, Executive Board Meeting 16/100,

November 9, Washington, D.C.: IMF.

2016i, 2016 External Sector Report, Washington, D.C.: IMF.

2016j, IMF Financial Operations, Washington, D.C.: IMF.

2016k, Guidance Note on the Assessment of Reserve Adequacy and

Related Considerations, Washington, D.C.: IMF.

2017a, Collaboration Between Regional Financial Arrangements and the

IMF, SM/17/190; June 29, Washington, D.C.: IMF.

2017b, "Are Countries Losing Control of Domestic Financial

Conditions?" Chapter 3 in Global Financial Stability Report, April, Washington, D.C.: IMF. 2017c, Status of Voluntary SDR Trading Arrangements and SDR

Designation Plan for the Period October 2017-September 2018, Washington, D.C.: IMF.

2017d, Adequacy of the Global Financial Safety Net-Review of the

Flexible Credit Line and Precautionary and Liquidity Line, and Proposals for Toolkit Reform SM/17/140, June 2, Washington, D.C.: IMF.

Ito, Hiro, and Menzie Chinn, 2015, "The Rise of the Redback: Evaluating the Prospects for RMB Use in Invoicing," in Barry Eichengreen and Masahiro Kawai, editors, Renminbi Internationalization: Achievements, Prospects, and Challenges, Washington, D.C.: Brookings Institution.

Kalemli-Ozcan, Sebnem, Elias Papaioannou, and Fabrizio Perri, 2013b, "Global banks and crisis transmission," Journal of International Economics 89: 495-510.

Kalemli-Ozcan, Sebnem, Elias Papaioannou, and Jose-Luis Peydro, 2013a, "Financial Regulation, Financial Globalization, and the Synchronization of Economic Activity," The Journal of Finance 68: 1179-1228.

Lane, Philip, and Peter McQuade, 2014, "Domestic Credit Growth and International Capital Flows," Scandinavian Journal of Economics 116: 218-252.

Lane, Philip, and Gian Maria Milesi-Ferretti, 2007, "The external wealth of nations mark II: Revised and extended estimates of foreign assets and liabilities, 1970-2004," Journal of International Economics 73: 223-250.

Leigh, Daniel, Weicheng Lian, Marcos Poplawski-Ribeiro, Rachel Szymanski, Viktor Tsyrennikov, and Hong Yang, 2017, "Exchange Rates and Trade: A Disconnect?" IMF Working Paper WP/17/58. 
Lindert, Peter, 1969 "Key Currencies and Gold, 1900-1913," Princeton Studies in International Finance No. 24, Princeton, N.J.: Princeton University Press.

Llaudes, Ricardo, Ferhan Salman, and Mali Chivakul, 2010, "The Impact of the Great Recession on Emerging Markets," IMF Working Paper WP/10/237.

Maggiori, Matteo, 2017, "Financial Intermediation, International Risk Sharing, and Reserve Currencies," American Economic Review 107(10): 3038-71.

McCauley, Robert, and Catherine Schenk, 2015, "Reforming the International Monetary System in the 1970s and 2000s: Would a Special Drawing Right Substitution Account Have Worked?" International Finance 18: 187-206.

McCauley, Robert, Patrick McGuire, and Vladyslav Sushko, 2015, "Global dollar credit: links to US monetary policy and leverage," Economic Policy 30: 187-229.

Mendoza, Enrique, Vincenzo Quadrini, and José-Victor Ríos-Rull, 2009, "Financial Integration, Financial Deepness and Global Imbalances," Journal of Political Economy 117: 371-416.

Miranda-Agrippino, Silvia, Helene Rey, 2015, "World Asset Markets and the Global Financial Cycle," NBER Working Paper No. 21722.

Monetary Authority of Singapore, 2017, "Project Ubin: SGD on Distributed Ledger"

Nurkse, Ragnar, 1944, International Currency Experience: Lessons of the Postwar Period, Princeton, NJ: League of Nations.

Obstfeld, Maurice, 2011, "International Liquidity: The Fiscal Dimension," Monetary and Economic Studies 29: 33-48.

Obstfeld, Maurice, 2013, "The International Monetary System: Living with Asymmetry," in Robert C. Feenstra and Alan M. Taylor, editors, Globalization in an Age of Crisis: Multilateral Cooperation in the Twenty-First Century. Chicago: University of Chicago Press.

Obstfeld, Maurice, 2017, "Comments on 'The Once and Future Global Imbalances? Interpreting the Post-Crisis Record' by Menzie D. Chinn," Jackson Hole Economic Policy Symposium, Federal Reserve Bank of Kansas City, August 24-26, 2017.

Obstfeld, Maurice, Jonathan Ostry, and Mahvash Qureshi, 2018, "Global Financial Cycles and the Exchange Rate Regime: A Perspective from Emerging Markets," America Economic Review Papers and Proceedings, forthcoming.

Obstfeld, Maurice, Jay Shambaugh, and Alan Taylor, 2010, "Financial Instability, the Trilemma, and International Reserves," American Economic Journal: Macroeconomics 2: 57-94.

Ocampo, José Antonio, 2010, "Building an SDR-Based Global Reserve System," Journal of Globalization and Development 1, Article 14.

Ocampo, José Antonio, 2014, "The provision of global liquidity: The global reserve system," WIDER Working Paper 2014/141. 
Ocampo, José Antonio, 2016, "A brief history of the international monetary system since Bretton Woods," WIDER Working Paper 2016/97.

Prasad, Eswar, 2014, The Dollar Trap: How the U.S. Dollar Tightened Its Grip on Global Finance, Princeton, NJ: Princeton University Press.

Quarles, Randal, 2017, "Thoughts on Prudent Innovation in the Payment System," Remarks at the 2017 Financial Stability and Fintech Conference, Washington, D.C., November 30.

Rey, Helene, 2015, “Dilemma not Trilemma: The Global Financial Cycle and Monetary Policy Independence," NBER Working Paper No. 21162.

Sahay, Ratna, and others, 2014, "Emerging Market Volatility: Lessons from the Taper Tantrum," IMF Staff Discussion Note SDN/14/09.

Scuffham, Matt, 2017, "Royal Bank of Canada using blockchain for U.S./Canada payments executive," Reuters Business News.

Singleton, John, and Catherine R. Schenk, 2015, "The Shift from Sterling to the Dollar 1965-76: Evidence from Australia and New Zealand," Economic History Review 68(4): 1154-1176.

Tovar, Camilo, 2018, "The Sleeping Beauty? Risk-Return Characteristics of SDR-Denominated Securities Markets," forthcoming IMF Working Paper.

Tovar, Camilo, and Tania Mohd Nor, 2018, "Reserve Currency Blocs: A Changing International Monetary System?" IMF Working Paper WP/18/20.

Triffin, Robert, 1960, Gold and the Dollar Crisis: The Future of Convertibility, New Haven, CT: Yale University Press.

Triffin International Foundation, 2014, Using the SDR as a Lever to Reform the International Monetary System: Report of an SDR Working Party, Louvain: Triffin International Foundation.

Truman, Edwin, 2008, "On What Terms is the IMF Worth Funding," Peterson Institute for International Economics Working Paper 08-11.

Truman, Edwin, 2011, "Three Evolutionary Proposals for Reform of the International Monetary System," Remarks delivered at the Bank of Italy Conference in Memory of Tommaso PadoaSchioppa.

Weder di Mauro, Beatrice, and Jeromin Zettelmeyer, 2017, "The New Global Financial Safety Net: Struggling for Coherent Governance in a Multipolar System," in Essays on International Finance, Vol. 4, Waterloo, Canada: Centre for International Governance Innovation. 